\title{
Trace element proxies for surface ocean conditions: A synthesis of culture calibrations with planktic foraminifera
}

\author{
Katherine A. Allen ${ }^{1,2 *}$, Bärbel Hönisch ${ }^{2}$, Stephen M. Eggins ${ }^{3}$, Laura L. Haynes ${ }^{2}$, Yair Rosenthal ${ }^{4}$, \\ Jimin $\mathrm{Yu}^{3}$ \\ 1 - School of Earth and Climate Sciences, University of Maine, Orono, ME, USA \\ 2 - Lamont-Doherty Earth Observatory of Columbia University, Palisades, NY, USA \\ 3 - Research School of Earth Sciences, The Australian National University, Canberra, ACT, \\ Australia \\ 4 - Department of Marine and Coastal Sciences, Rutgers University, New Brunswick, NJ, USA \\ *corresponding author: katherine.a.allen@maine.edu
}

\begin{abstract}
The trace element composition of planktic foraminiferal calcite provides a useful means of determining past surface ocean conditions. We have assembled the results of culture experiments for three species of symbiont-bearing planktic foraminifera, Globigerinoides ruber, Globigerinoides sacculifer, and Orbulina universa, and one symbiont-barren species, Globigerina bulloides, to evaluate their responses to temperature, salinity, $\mathrm{pH}$, carbonate ion, and dissolved inorganic carbon (DIC) growth conditions. Trace element ratios $(\mathrm{Li} / \mathrm{Ca}, \mathrm{B} / \mathrm{Ca}, \mathrm{Mg} / \mathrm{Ca}, \mathrm{Sr} / \mathrm{Ca}, \mathrm{Mn} / \mathrm{Ca}, \mathrm{Cd} / \mathrm{Ca}, \mathrm{Ba} / \mathrm{Ca}, \mathrm{Na} / \mathrm{Ca}$, and $\mathrm{U} / \mathrm{Ca}$ ) were measured simultaneously on samples grown with the same culture techniques, which provides robust, relatable calibrations that may be used together in multi-proxy paleoceanographic studies. Our data confirm that temperature is the dominant control on foraminiferal $\mathrm{Mg} / \mathrm{Ca}$ under the ranges of conditions studied and that the potential effects of salinity and $\mathrm{CO}_{3}{ }^{2-}$ on $\mathrm{Mg} / \mathrm{Ca}$ of these tropical species across late Pleistocene glacial cycles are relatively small. Carbonate system experiments suggest that $\mathrm{Sr} / \mathrm{Ca}$ may be useful for reconstructing large DIC changes. $\mathrm{Na} / \mathrm{Ca}$ increases with salinity in $\mathrm{G}$. ruber (pink), but not in G. sacculifer. As these emerging proxy relationships become more firmly established, the synthesis of multiple trace element ratios may help paleoceanographers isolate the effects of different environmental parameters in paleo records. Calcification rates $(\mu \mathrm{g} /$ day) vary among species and do not respond consistently to any experimental parameter. Comparison of our calcification rates with those observed in inorganic calcite precipitation experiments suggest that foraminifera calcify $\sim 100 \mathrm{x}$ more slowly than inorganic calcites grown in similar solutions. We suggest that calcification rate does not typically exert a dominant control on trace element partitioning in planktic foraminiferal calcite, though it may play a role for some elements under certain circumstances. Differences in average growth rate cannot explain composition differences among species, pointing to alternative controls that may be biological in origin.
\end{abstract}

\section{Introduction}

Shells (tests) of foraminifera preserved on the sea floor constitute an important archive for paleoceanographers, and much has been done in recent decades to quantify and understand relationships between the composition of foraminiferal calcite and the 
environmental conditions in which foraminifers have grown. The shell of modern planktic foraminifera is composed of calcite, the trigonal polymorph of $\mathrm{CaCO}_{3}$. Calcite's flexible corner-sharing structure allows it to accommodate a wide range of trace elements (Reeder, 1983), but the total contribution of trace elements to foraminiferal calcite is typically less than $2 \%$ (moles of trace elements / moles calcium x 100), including Li, B, F, Na, Mg, P, V, Mn, Fe, Cu, Zn, Sr, Cd, Ba, Nd, and U (Lea, 1999). Laboratory and field studies have shown that changes in environmental conditions such as temperature and seawater carbonate ion concentration $\left(\left[\mathrm{CO}_{3}{ }^{2-}\right]\right)$ can produce predictable variations in the trace element composition of foraminiferal calcite (e.g., Anand et al., 2003; Lea et al., 1999; Russell et al., 2004). Assuming that fossil foraminifera behaved similarly to these modern specimens, the calibration of these variations can be used to infer past environmental changes.

60

61

62

In this study we report the chemical composition of calcite precipitated in culture experiments by planktic foraminifera, specifically the ratios of lithium, magnesium, strontium, manganese, cadmium, sodium, and uranium to calcium $(\mathrm{Li} / \mathrm{Ca}, \mathrm{Mg} / \mathrm{Ca}, \mathrm{Sr} / \mathrm{Ca}$, $\mathrm{Mn} / \mathrm{Ca}, \mathrm{Cd} / \mathrm{Ca}, \mathrm{Na} / \mathrm{Ca}$, and $\mathrm{U} / \mathrm{Ca}$ ). In previous studies, these ratios have often been considered separately, and one of our goals is to consider a wide variety of trace elements to gain new insight into these proxies. Some models of trace element incorporation predict different partitioning behavior for different elements due to variations in chemical properties (e.g., ionic radius, charge). Therefore a holistic approach that includes a wide range of elements enables testing of these predictions. For example, Elderfield et al. (1996) analyzed a suite of trace element ratios to test the idea that Rayleigh distillation from an internal pool or reservoir could explain trace element partitioning during foraminiferal calcification. Their results provided some support for this model in benthic foraminifera, but not in planktics. Later studies built on the pioneering work of Elderfield et al. by considering the distribution of multiple elements within single shells (e.g., Hathorne et al., 2009), which confirmed the earlier studies' findings regarding the lack of Rayleigh-distillation behavior in planktics and also provided a detailed picture of microscale trace element distribution patterns.

78

79

80

81

82

83

84

85

86

87

88

89

90

91

92

93

Here, we synthesize a suite of trace element and calcification rate data to assess controls on the composition of foraminiferal calcite. We aim to assess whether some recent models for trace element incorporation in inorganic carbonates may apply to foraminifera as well. According to one growth-entrapment model of trace element incorporation (DePaolo, 2011), as mineral growth rates increase, incorporation of cations larger than $\mathrm{Ca}^{2+}$ (hereafter "large" ions) should increase while incorporation of cations smaller than $\mathrm{Ca}^{2+}$ ("small" ions) should decrease. The underlying idea is that larger ions are easier to dehydrate, which might lead to greater rates of incorporation compared to smaller, more strongly hydrated ions at higher growth rates. Another growth-entrapment model is based on the idea that trace element incorporation is determined by the competing effects of crystal growth rate and diffusivity of ions in the near-surface region of a growing crystal (Watson, 1996 and 2004). These two models invoke different mechanisms but produce similar predictions regarding trace metal inclusion in calcite. If such growth-rate effects exerted a dominant influence on foraminifera, we should see an inverse relationship between concentrations of large cations $\left(\mathrm{Sr}^{2+}, \mathrm{Ba}^{2+}\right)$ and small cations $\left(\mathrm{Mg}^{2+}, \mathrm{Mn}^{2+}, \mathrm{Cd}^{2+}\right)$ 
94 in foraminiferal calcite. Our large suite of trace element data measured on the same

95 samples allows this kind of hypothesis to be tested.

96

97

98

99

100

101

102

103

104

105

106

107

108

109

110

111

112

113

114

115

116

117

118

119

120

121

122

123

124

125

126

127

128

129

130

131

132

133

134

135

136

137

138
First, to provide context for our new results, we summarize existing knowledge and observations from both field-based studies and laboratory-based culture experiments.

\subsection{Large divalent cations}

\section{$\mathrm{Sr} / \mathrm{Ca}$}

Both culture and field studies demonstrate $\mathrm{Sr} / \mathrm{Ca}$ of planktonic foraminiferal calcite is not influenced strongly by temperature or salinity (e.g., Lea et al. 1999), but do suggest increases with shell calcification rate (Dueñas-Bohórquez et al., 2009; Elderfield et al., 2002; Kisakürek et al., 2008; Lea et al., 1999b). This is consistent with observations of increased $\mathrm{Sr}$ incorporation in calcite at higher precipitation rates in inorganic precipitation studies (Gabitov and Watson, 2006; Lorens, 1981; Paquette and Reeder, 1995), and suggests observed increases with temperature and salinity in planktic foraminifer shells may be an indirect effect of enhanced calcification rate (DueñasBohórquez et al., 2009). Systematic variations in planktic foraminifer shell $\mathrm{Sr} / \mathrm{Ca}$ in the geologic record have been attributed to changes in seawater $\mathrm{Sr} / \mathrm{Ca}$, and also to $\left[\mathrm{CO}_{3}{ }^{2-}\right]$ and nutrient availability (Billups et al., 2004; Martin et al., 1999; Stoll et al., 1999). As with temperature and salinity, these latter factors might be linked to their influence on foraminifer calcification rates. $\mathrm{Sr} / \mathrm{Ca}$ varies little within single shells (Hathorne et al., 2009).

\section{$\mathrm{Ba} / \mathrm{Ca}$}

Previous culture studies have demonstrated that $\mathrm{Ba} / \mathrm{Ca}$ of foraminiferal calcite exhibits no detectable response to salinity, temperature, or carbonate system parameters; rather, it increases linearly with $\mathrm{Ba} / \mathrm{Ca}$ of seawater (Lea and Spero, 1994; Hönisch et al., 2011). Empirical evidence for the influence of growth rate on $\mathrm{Ba} / \mathrm{Ca}$ of inorganic calcite is mixed, with some experiments suggesting an increase in $\mathrm{Ba}$ incorporation with growth rate (Tesoriero and Pankow, 1996) and others suggesting Ba incorporation is independent of growth rate (Pingitore and Eastman, 1984). As a result of its strong dependence on $\mathrm{Ba} / \mathrm{Ca}$ of seawater, $\mathrm{Ba} / \mathrm{Ca}$ of foraminiferal calcite has been used to track ocean processes that involve changes in seawater $\mathrm{Ba} / \mathrm{Ca}$, such as freshwater runoff (which has much higher [Ba] than seawater) and remineralization of Ba-rich biogenic particles in the deep ocean (e.g., Hall and Chan, 2004). Since results of our culture experiments have been thoroughly discussed in Hönisch et al. (2011), we only discuss them here in the context of the trace element suite.

\subsection{Small divalent cations}

$\mathrm{Cd} / \mathrm{Ca}$ 
Based on a core-top study in the North Atlantic, Rickaby and Elderfield (1999) suggested that $\mathrm{Cd}$ incorporation in some species is influenced by temperature. The effect of salinity has not yet been extensively tested. Experiments with inorganic calcite suggest that $\mathrm{Cd}$ incorporation decreases as growth rate increases (Lorens, 1981; Tesoriero and Pankow, 1996). $\mathrm{Cd} / \mathrm{Ca}$ in planktic foraminifera has been used as a proxy for phosphate concentration in seawater (Boyle, 1988; Delaney, 1989; Yu et al., 2013). This is based on the strong correlation that exists between $\mathrm{Cd}$ and phosphate and also ${ }^{13} \mathrm{C}$ in the modern ocean. The response of planktonic foraminiferal $\mathrm{Cd} / \mathrm{Ca}$ to seawater nutrients is speciesspecific. Globigerina bulloides' $\mathrm{Cd} / \mathrm{Ca}$ appears to reflect seawater $\mathrm{Cd}$ concentrations (Mashiotta et al., 1997), while symbiont-bearing species are characterized by much lower Cd incorporation (Mashiotta et al., 1997; Ripperger et al., 2008).

\section{$\mathrm{Mn} / \mathrm{Ca}$}

Temperature, salinity, and carbonate system influences on $\mathrm{Mn} / \mathrm{Ca}$ incorporation in planktonic foraminifera have not previously been tested in culture experiments. In inorganic experiments, $\mathrm{Mn} / \mathrm{Ca}$ of calcite overgrowths has been observed to increase with precipitation rate (Mucci, 1988). The amount of Mn dissolved in seawater is influenced by terrestrial input and redox reactions, and $\mathrm{Mn} / \mathrm{Ca}$ of foraminiferal calcite has been used to infer changes in these processes across the last glacial cycle (Klinkhammer et al., 2009). Based on core-top samples, $\mathrm{Mn} / \mathrm{Ca}$ has also been interpreted to reflect nutrient content of surface waters (Marr et al., 2013).

\section{$\mathrm{Mg} / \mathrm{Ca}$}

Field-based and laboratory culture studies have consistently shown $\mathrm{Mg} / \mathrm{Ca}$ to increase with temperature at a rate of $8-10 \%$ per ${ }^{\circ} \mathrm{C}$ (Delaney et al., 1985; Lea et al., 1999b; Kisakürek et al., 2008) and to increase with salinity (Ferguson et al., 2008; DueñasBohórquez et al., 2009; Hönisch et al., 2013; Kısakürek et al., 2008; Lea et al., 1999b; Nürnberg et al., 1996). These studies provide the foundation for using foraminiferal $\mathrm{Mg} / \mathrm{Ca}$ as a highly sensitive temperature proxy. Culture experiments have further revealed the $\mathrm{Mg} / \mathrm{Ca}$ composition of $O$. univers $a$ and G. bulloides to decrease as seawater $\mathrm{pH}$ and $\left[\mathrm{CO}_{3}{ }^{2-}\right]$ increase (Evans et al., 2016; Kisakürek et al., 2008; Lea et al., 1999b; Russell et al., 2004). Russell et al. (2004) suggested that the effect becomes negligible above a certain $\left[\mathrm{CO}_{3}{ }^{2-}\right]$ threshold. In a recent compilation of $\mathrm{Mg} / \mathrm{Ca}$ data from culture experiments, Evans et al. (2016) find that $\mathrm{Mg} / \mathrm{Ca}$ decreases linearly with $\left[\mathrm{CO}_{3}{ }^{2-}\right]$ with no threshold and they also provide a logistic fit for the $\mathrm{Mg} / \mathrm{Ca}-\mathrm{pH}$ relationship that includes two inflection points. Because $\mathrm{pH}$ and $\left[\mathrm{CO}_{3}{ }^{2-}\right]$ covary in all of these experiments, it has not yet been possible to distinguish between a $\mathrm{pH}$ and a $\left[\mathrm{CO}_{3}{ }^{2-}\right]$ control. Relative $\mathrm{Mg} / \mathrm{Ca}$ enrichment at low $\mathrm{pH}$ could be the result of reduced efficiency of $\mathrm{Mg}$ removal from the calcifying fluid in the presence of higher $\left[\mathrm{H}^{+}\right]$(Evans et al., 2015). Results of culture experiments are notably different from inorganic calcite precipitation experiments, which produce much smaller $\mathrm{Mg} / \mathrm{Ca}$ sensitivity to temperature (ca. $2-3 \%$ per ${ }^{\circ} \mathrm{C}$ ) and much higher $\mathrm{Mg} / \mathrm{Ca}$ calcite ratios when precipitation occurs from seawater (by 1 to 2 orders of magnitude) (reviewed in Lea, 2003). 
$\mathrm{Mg} / \mathrm{Ca}$ in planktic foraminiferal calcite is typically 1-2 orders of magnitude lower than that of inorganic calcite (e.g., Mucci and Morse, 1983; Oomori et al., 1987; Hartley and Mucci, 1996), and it has been suggested that foraminifera may actively remove $\mathrm{Mg}$ ions from calcification fluids via trans-membrane channels or pumps (Zeebe and Sanyal, 2002; Bentov and Erez, 2006). Intrashell variation in a series of high/low (night/day) $\mathrm{Mg}$ bands may be related to variable Mg uptake by mitochondria (Spero et al., 2015).

\subsection{Other ions \\ $\mathrm{U} / \mathrm{Ca}$}

No significant U/Ca-temperature relationship has been observed in culture experiments, but $\mathrm{Yu}$ et al. (2008) report a positive correlation between $\mathrm{U} / \mathrm{Ca}$ and temperature for Globigerina bulloides, Neogloboquadrina pachyderma, and Globorotalia inflata in coretop samples from the North Atlantic. Evidence from previous culture experiments suggests $\mathrm{U} / \mathrm{Ca}$ decreases with $\left[\mathrm{CO}_{3}{ }^{2-}\right]$ and $\mathrm{pH}$ (Russell et al., 2004), and $\mathrm{U} / \mathrm{Ca}$ has been observed to decrease with $\left[\mathrm{CO}_{3}{ }^{2-}\right]$ in benthic foraminifera as well (Raitzsch et al., 2011; Keul et al., 2013). These relationships are broadly consistent with the incorporation of uranyl ion $\left(\mathrm{UO}_{2}{ }^{2+}\right)$ as rutherfordine $\left(\mathrm{UO}_{2} \mathrm{CO}_{3}\right)$ into calcite, which is the result of changes in uranium speciation with $\left[\mathrm{CO}_{3}{ }^{2-}\right]$ and $\mathrm{pH}$ in seawater (e.g., Djogić and Branica, 1991). Results of inorganic calcite growth experiments suggest that $\mathrm{U}$ incorporation is strongly influenced by properties of the crystal surface, with a possible role for growth rate (Reeder et al., 2001).

\section{$\mathrm{Li} / \mathrm{Ca}$}

Temperature does not exert a measurable effect on $\mathrm{Li} / \mathrm{Ca}$ in cultured G. sacculifer (Delaney and Bé, 1985). Field investigations of a temperature-Li/Ca link yield different results for different species. Temperature was ruled out as a key control on $\mathrm{Li} / \mathrm{Ca}$ in $O$. universa based on a study of North Atlantic core-top and down-core samples, from which pressure and dissolution could also be eliminated as factors (Hall and Chan, 2004), while in N. pachyderma (s), Li/Ca increases linearly with temperature (Hendry et al., 2009). It is not clear whether salinity exerts control on $\mathrm{Li} / \mathrm{Ca}$ of planktic foraminifera, but in inorganic calcite, $\mathrm{Li} / \mathrm{Ca}$ has been observed to increase four-fold between salinities of 10 and 50 (Marriott et al., 2004), which encompasses a much larger range than typical seawater variations. Early culture experiments indicated $\mathrm{Li} / \mathrm{Ca}$ in planktic foraminifer shells responded to seawater $\mathrm{Li} / \mathrm{Ca}$, though not in a strictly linear fashion (Delaney and Bé, 1985). This relationship was subsequently applied to the fossil record to infer changes in seafloor hydrothermal fluxes and oceanic crust formation rates (Delaney and Boyle, 1986). Later work revealed systematic foraminiferal $\mathrm{Li} / \mathrm{Ca}$ variations across late Pleistocene glacial cycles, which prompted a search for additional controls on $\mathrm{Li}$ incorporation because the observed changes were too rapid to be explained by plausible rates of change in the ocean's Li inventory (Hall and Chan, 2004; Hall et al., 2005). Instead, Hall and Chan (2004) proposed a $\left[\mathrm{CO}_{3}{ }^{2-}\right]$-driven growth rate control on $\mathrm{Li}$ incorporation, but this relationship has not yet been tested in laboratory culture. 
$\mathrm{Na} / \mathrm{Ca}$ has been proposed as a proxy for salinity based on culture experiments with the benthic foraminifer Ammonia tepida (Wit et al., 2013), but no systematic relationships have yet been reported for planktic foraminifera, and the influence of temperature has not been tested. The Na content of some natural carbonates including limestone, travertine, and invertebrate shells reflects seawater salinity (Gordon et al., 1970; Ichikuni and Kikuchi, 1972; Sakae et al., 1979), but the positive correlation is only robust between 0 and 10 salinity units (Ishikawa and Ichikuni, 1984). The free $\mathrm{Na}$ ion is univalent $(+1)$ and its incorporation is thought to proceed differently from many of the elements discussed above, which substitute directly for $\mathrm{Ca}^{2+}$ as divalent $(+2)$ cations in the calcite lattice (this may also apply to $\mathrm{Li}^{+}$). In inorganic calcites, $\mathrm{Na}$ occupies interstitial positions between carbonate ions and $\mathrm{CaO}_{6}$ octahedra (Busenberg and Plummer, 1985; Ishikawa and Ichikuni, 1984; White, 1978), and the amount of Na incorporated varies as a function of crystal growth rate, possibly because the number of crystal defects (and interstitial spaces) increases as growth rates increase (Busenberg and Plummer, 1985).

$\mathrm{B} / \mathrm{Ca}$

In shells of cultured planktonic foraminifera, $\mathrm{B} / \mathrm{Ca}$ increases with $\mathrm{pH}$ of the culture solution (e.g., Sanyal et al., 2001; Allen et al., 2011; Allen et al., 2012; Henehan et al., $2015)$, broadly consistent with the prediction that $B$ incorporation should increase as seawater borate $\left(\mathrm{B}(\mathrm{OH})_{4}{ }^{-}\right)$concentrations increase (Hemming and Hanson, 1992). B/Ca is not only sensitive to $\mathrm{B}(\mathrm{OH})_{4}{ }^{-}$, but to the relative abundance of $\mathrm{B}(\mathrm{OH})_{4}{ }^{-}$and dissolved inorganic carbonate species, $\mathrm{B}(\mathrm{OH})_{4}{ }^{-} / \mathrm{HCO}_{3}{ }^{-}$or perhaps $\mathrm{B}(\mathrm{OH})_{4}{ }^{-} / \mathrm{DIC}(\mathrm{Yu}$ et al., 2007; Allen et al., 2012). In cultured O. universa, G. ruber and G. sacculifer, B/Ca increases linearly with salinity and total seawater $\mathrm{B}$ concentration $\left(\mathrm{B}_{\mathrm{T}}\right)$, but exhibits no significant response to temperature (Allen et al., 2012). B/Ca of core-top G. inflata and G. bulloides increases with temperature ( $\mathrm{Yu}$ et al., 2007); however, covariation of temperature with salinity and carbonate system parameters in these surface waters precludes a clear assessment of a B/Ca-temperature relationship based on core-top data alone (Allen and Hönisch, 2012). Results from inorganic calcite growth experiments suggest that $\mathrm{B} / \mathrm{Ca}$ increases with growth rate and with $\mathrm{B}_{\mathrm{T}}$ /DIC (Uchikawa et al., 2015). Samples from Bermuda sediment traps reveal that $\mathrm{B} / \mathrm{Ca}$ in $G$. ruber (white) varies seasonally, perhaps as a result of shifting micro-environment chemistry driven by variable symbiont activity (Babila et al., 2014). Henehan et al. (2015) find a positive correlation between $\mathrm{B} / \mathrm{Ca}$ and seawater phosphate $\left(\mathrm{PO}_{4}{ }^{3-}\right)$ based on $G$. ruber (white) core-top data; the influence of nutrient concentrations merits further investigation.

By systematically altering temperature, salinity, $\mathrm{pH}$ and DIC growth conditions in a suite of laboratory culture experiments, we aim to improve our understanding of controls on incorporation of these trace elements in planktic foraminiferal calcite. In the following discussion, we synthesize a multi-element dataset and compare our results with other studies to test and extend existing proxy calibrations.

\section{Methods}




\subsection{Culture experiments}

This study incorporates new results from experiments conducted on Santa Catalina Island and Puerto Rico (G. ruber, G. sacculifer, O. universa, and G. bulloides) and previously reported results from Allen et al. (2011) (O. universa) and Allen et al. (2012) (G. ruber (pink) and G. sacculifer). Culture experiments and analytical methods are summarized below; detailed descriptions are provided in the previous publications.

Culture experiments were performed at the Wrigley Marine Science Center on Santa Catalina Island $\left(33^{\circ} 26^{\prime} 40^{\prime \prime} \mathrm{N}, 118^{\circ} 28^{\prime} 55^{\prime \prime} \mathrm{W}\right)$ during summers 2000,2008 , and 2013 , and at the University of Puerto Rico's Marine Sciences Center on Isla Magueyes (collection site $17^{\circ} 52^{\prime} \mathrm{N}, 66^{\circ} 58^{\prime} \mathrm{W}$ ) during March and April 2010. Juvenile foraminifers were handcollected by SCUBA divers in open ocean conditions either two (Catalina Island) or eight (Puerto Rico) nautical miles offshore and between 2 and 8 meters depth. Immediately after collection, samples were brought to the laboratory, where the foraminifera were identified and their maximum shell diameters were determined using inverted light microscopes. Specimens were then transferred to individual $120 \mathrm{~mL}$ soda lime glass jars filled with experimental seawater and sealed with snap lids to prevent gas exchange with the atmosphere. Seawater used in these culture experiments was collected offshore and filtered $(0.8 \mu \mathrm{m})$ to remove large particles, with the exception of the low-DIC experiment that consisted of half natural (filtered) and half artificial seawater (MilliQ water plus salts (see Allen et al., 2012). Experiments were designed to vary either temperature, salinity, or carbonate system parameters separately. Approximately 20 O. universa, $20 \mathrm{G}$. sacculifer, and 50 G. ruber (pink) specimens were cultured for each experimental condition, and individually fed a one-day-old brine shrimp nauplius (Artemia salina) every other day. Cultures were maintained in temperature-controlled water baths and illuminated using cool white fluorescent lamps on a strict diurnal cycle: 12 hours light, 12 hours dark. Over the course of $1-3$ weeks, foraminifers grew new chambers on their calcite shells to accommodate cytoplasm growth. Experiments ended after a specimen underwent gametogenesis. The remaining empty calcite shell was then rinsed in deionized water, dried, and archived for later analysis. The maximum shell diameter after gametogenesis was measured to determine total growth under the experimental conditions.

The desired $\mathrm{pH}(7.5-8.6$, total scale) of experimental seawater was set by titrating filtered seawater with $\mathrm{NaOH}$ or ultrapure $\mathrm{HCl}$. Salinity was varied between 30 and $40 \pm$ 0.1 by diluting seawater with deionized water or by partial evaporation under a heat lamp at $60^{\circ} \mathrm{C}$. Culture jars were placed in separate, temperature-controlled water baths, the temperatures of which were set to specific values that ranged between $17.7 \pm 0.5$ and 29.3 $\pm 0.2{ }^{\circ} \mathrm{C}( \pm 1 \sigma)$. To monitor for $\mathrm{CO}_{2}$ exchange with the laboratory atmosphere during feeding (when caps must be removed), as well as the net effects of respiration, photosynthesis and calcification, alkalinity and $\mathrm{pH}$ were measured at the beginning and end of each experiment using a Metrohm 809 open cell auto-titrator and $\mathrm{pH}$ meter, calibrated with NIST buffers and Dickson-certified alkalinity standards. After analysis, 
$\mathrm{pH}$ values measured on the NBS scale were converted to the total scale according to the

Additional culture experiments with $O$. universa were carried out during July and August of 2013 on Santa Catalina Island to investigate proxy relationships under Paleocene seawater chemistry. Sample collection and experimental methods follow procedures nearly identical to those above. Experimental seawater batches were composed of half artificial and half natural (filtered) seawater, but concentrations of $\mathrm{Ca}, \mathrm{Mg}$, and $\mathrm{B}$ were modified to reflect estimated Paleocene values $(20 \mathrm{mmol} / \mathrm{kg}, 30 \mathrm{mmol} / \mathrm{kg}$, and 365 $\mu \mathrm{mol} / \mathrm{kg}$, respectively, at a salinity of 33.1-33.3 see Table S1) (Tyrell and Zeebe 2004, Lemarchand et al. 2000). Resultant $\mathrm{Sr} / \mathrm{Ca}$ sw values were thus roughly half of modern $(4.58 \mathrm{mmol} / \mathrm{mol}$ on average). DIC was varied independently from $\mathrm{pH}$ by the addition of $\mathrm{NaHCO}_{3}$ to reach target values ranging from $1000-4000 \mu \mathrm{mol} / \mathrm{kg}$.

\subsection{Carbonate system calculation}

The Matlab program CO2SYS.m was used to calculate carbonate system parameters from measured values of seawater $\mathrm{pH}$, alkalinity, temperature and salinity (van Heuven, 2011). Values presented in Table S1 are averages determined for each experiment $(\mathrm{n} \approx 10$ measurements per batch of seawater). Carbonate system calculations assume atmospheric pressure (1 atm), Mehrbach et al. (1973) constants for the dissociation of carbonic acid and bicarbonate, $\mathrm{K} 1$ and $\mathrm{K} 2$, refit by Lueker et al. (2000) on the total $\mathrm{pH}$ scale, $\mathrm{KSO}_{4}$ dissociation constant recommended by Dickson et al. (2007) and total boron of Uppström (1974), which was used for the sake of consistency with previous studies. The CO2SYS.m script was modified to allow inputs for [Ca], [Mg], and [B] of seawater and using $\mathrm{K} 1$ and $\mathrm{K} 2$ constant sensitivities to $[\mathrm{Mg}],[\mathrm{Ca}]$, and $[\mathrm{Na}]$ as in Ben-Yaakov and Goldhaber (1973).

\subsection{Sample preparation}

The calcite shells produced by foraminifers in these culture experiments were composed of chambers grown in the open ocean before collection (unconstrained, unknown conditions) and chambers grown in experimental seawater (controlled, constant conditions). For $O$. universa specimens, the contribution of juvenile chambers to the final shell weight is insignificant (Spero and Parker, 1985), and gametogenic spheres grown in culture experiments were simply cracked in half and analyzed without attempting to remove any juvenile chamber fragments. In the case of G. sacculifer and G. ruber, the contribution of open-ocean calcite to the final shell is not negligible, and was removed to enable analysis of calcite that was produced only under controlled experimental conditions. This was achieved by amputation of chambers grown during the experimental period using a medical scalpel blade under a light microscope. These amputated chambers were then weighed and pooled to make a single sample (comprising approximately 20 to 80 chambers per experiment to yield a total of $400 \mu \mathrm{g}$ of calcite).

Samples were cleaned according to the methods of Russell et al. (2004), using two 30minute treatments of a hot, buffered hydrogen peroxide solution (equal parts $0.1 \mathrm{~N} \mathrm{NaOH}$ 
$+30 \% \mathrm{H}_{2} \mathrm{O}_{2}, 70-80^{\circ} \mathrm{C}$ ) to remove organic matter. Finally, all cleaned samples were rinsed 3 times with ultrapure Milli- $\mathrm{Q}^{+}$water that had been passed through a boron Q-gard purification filter, briefly leached with $0.001 \mathrm{~N} \mathrm{HNO}_{3}$, and rinsed again 3 times with Milli- $\mathrm{Q}^{+}$water. Immediately prior to analysis, samples were dissolved in $0.65 \mathrm{~N}^{\mathrm{HNO}_{3}}$ (trace element grade).

\subsection{Analysis}

Elemental composition of calcite samples was determined by inductively coupled plasma mass spectrometry (ICP-MS). Orbulina universa samples (2008 culture season) were analyzed in the Godwin Laboratory of Cambridge University (PerkinElmer SCIEX Elan DRC II), where the calcium concentration ([Ca]) of each sample solution was diluted to $100 \mathrm{ppm}$ to avoid matrix effects on trace element ratios (Yu et al., 2005). Globigerinoides samples and $O$. universa samples from 2010 and 2013 were analyzed at Rutgers University (Thermo Scientific Element XR), where standard solutions with differing [Ca] $(1.5-8 \mathrm{mM})$ were run to quantify and correct for any matrix effects. At Cambridge, within-run precision of an internal standard solution was $<1 \%$ for all ratios analyzed; long-term precision reported as Relative Standard Deviation $(\mathrm{RSD}=$ [Standard Deviation/Average Value $\left.]^{*} 100\right)$ is $2.4 \%(\mathrm{Li} / \mathrm{Ca}), 1.4 \%(\mathrm{Mg} / \mathrm{Ca}), 0.9 \%(\mathrm{Mn} / \mathrm{Ca}), 0.9 \%$ $(\mathrm{Sr} / \mathrm{Ca}), 2.4 \%(\mathrm{Cd} / \mathrm{Ca})$, and $2.5 \%(\mathrm{U} / \mathrm{Ca})(\mathrm{Yu}$ et al., 2005). At Rutgers, within-run precision of three standard solutions was $<3 \%$ for all ratios analyzed; long-term precision $(\mathrm{RSD})$ is $5.8 \%(\mathrm{Li} / \mathrm{Ca}), 2.3 \%(\mathrm{Mg} / \mathrm{Ca})$, and $4.0 \%(\mathrm{Sr} / \mathrm{Ca})$. Long-term precision data were not available for $\mathrm{Na} / \mathrm{Ca}$; instead, uncertainty was estimated as the maximum difference $(1.7 \%)$ between consistency standard values determined at the beginning and end of the run. $\mathrm{Na} / \mathrm{Ca}$ error bars in figures represent the largest \% difference among 3 consistency standards analyzed at the beginning and end of each run, or the $1 \sigma$ of replicate measurements, whichever is larger.

Elemental composition of seawater from O. universa experiments (2013) was determined via simultaneous ICP-AES at the Australian National University (axial Varian Vista Pro). Experimental seawater was sampled before and after culturing, filtered with a $0.2 \mu \mathrm{m}$ filter, acidified with $150 \mu 1 \mathrm{HCl}$ (Aristar 30\%), covered with Parafilm and a screw top lid, and stored until analysis in the spring of 2014. Prior to analysis, samples were diluted 10x with $2 \% \mathrm{HNO}_{3}$ and then run using a standard-sample-standard bracketing routine with a synthetic seawater standard of known elemental concentrations. Initial and final seawater elemental compositions were averaged to determine experimental values (Table S1). Analytical precision (RSD) for seawater B/Ca, $\mathrm{Mg} / \mathrm{Ca}$, and $\mathrm{Sr} / \mathrm{Ca}$ was $0.3,0.2$, and $0.2 \%$, respectively.

Orbulina universa produced more calcite in culture than either G. ruber or G. sacculifer, allowing a larger number of elements to be measured for $O$. universa than for other species (Table S1). Globigerinoides ruber or G. sacculifer samples were limited to the determination of $\mathrm{Li}, \mathrm{B}, \mathrm{Mg}, \mathrm{Ca}, \mathrm{Sr}$, and $\mathrm{Na} . \mathrm{B}, \mathrm{Mg}$, and $\mathrm{Ba}$ results are reported in Allen et al., (2012), Hönisch et al. (2013), and Hönisch et al (2011), respectively.

\subsection{Assessment of correlation}


415 To assess correlations between trace element ratios and environmental parameters, 416 Pearson linear correlation coefficients (R) and corresponding $\mathrm{p}$ values were calculated. 417 Values of $\mathrm{p}<0.05$ indicate $>95 \%$ confidence that the $\mathrm{R}$ (or $\mathrm{R}^{2}$ ) value differs from zero. 418 In this study, relationships with $\mathrm{p} \leq 0.05$ are considered significant; a few borderline relationships $(0.05>\mathrm{p}<0.1)$ are discussed as well. All $\mathrm{p}$ values (including those $>0.05$ ) are reported in Tables 2 (element-experimental parameter) and S1 (element-element). Exponential or other curved relationships may fail this type of significance test, so Spearman rank correlations were also evaluated to check for non-linear behavior. Results of these two tests were largely consistent and as a result the more commonly used linear Pearson coefficients are presented. Correlations were calculated using individual data points (Table S1), not experiment averages.

\subsection{Estimation of net calcification rates}

Net calcification rates were estimated for each cultured foraminifer by dividing the weight of calcite grown in culture by the number of growth days in culture ( $\mu \mathrm{g} /$ day). For $O$. universa, the final sphere weight for each specimen was divided by the number of days that particular specimen lived between sphere formation and gametogenesis. The trochospiral shell is very small and often absent in adult shells; its contribution to the final weight was assumed to be negligible. For $G$. sacculifer and $G$. ruber, the total weight of chambers grown in culture (i.e., the amputated chambers) for each individual was divided by the total number of days that individual spent in culture. Chambers amputated from $G$. bulloides were too small to be weighed individually; their weight was typically below the detection limit of the balance. Instead, the weight of amputated chambers was estimated from the final pre-amputated shell weight $\left(\mathrm{W}_{\mathrm{F}}\right)$ and the difference between the final shell diameter $\left(\mathrm{D}_{\mathrm{F}}\right)$ and the amputated diameter $\left(\mathrm{D}_{\mathrm{A}}\right)$ according to the following equation: $\mathrm{W}_{\mathrm{A}}=\mathrm{W}_{\mathrm{F}} \mathrm{x}\left(\mathrm{D}_{\mathrm{A}}-\mathrm{D}_{\mathrm{F}}\right)$. Finally, calcification rates determined for all specimens $(n=551)$ were used to determine averages for each experiment. The average number of specimens in each experiment was $\sim 20$. Typical net calcification rates for each species were determined by averaging the results of all temperature, salinity, and $\mathrm{pH}$ experiments (excluding DIC experiments, which were only conducted with $G$. sacculifer).

Surface areas of cultured shells were not measured. However, to provide area-normalized estimates of calcification rates for comparison with inorganic precipitation studies (e.g., Uchikawa et al., 2015), shell surface areas were approximated according to a weightsurface area relationship for planktic foraminifera determined by the Brunauer-EmmettTeller method (Gehlen et al., 2005). We chose the value determined from the shallowest samples in the Gehlen et al. (2005) study $\left(1.9 \mathrm{~m}^{2} / \mathrm{g}\right)$ because those sediments are most likely to be well preserved and therefore most analogous to our freshly cultured samples. Rates reported in $\mu \mathrm{g} /$ day (described above) were converted to mol/second assuming $100.1 \mathrm{~g} / \mathrm{mol} \mathrm{CaCO}_{3}$. Finally, these values were divided by surface areas calculated from individual shell weights to estimate calcification rates in units of $\mathrm{mol} \mathrm{m}^{-2} \mathrm{~s}^{-1}$.

458

459

\section{Results}


Different species exhibit different average calcification rates: G. bulloides $(0.3 \mu \mathrm{g} / \mathrm{day})<$ G. ruber $(1 \mu \mathrm{g} /$ day $)<$ G. sacculifer $(3 \mu \mathrm{g} /$ day $)<O$. universa $(6 \mu \mathrm{g} /$ day) (Fig. 8). All species means are distinct from one another at a $95 \%$ confidence level. When converted to mol m $\mathrm{m}^{-1}$ assuming a surface area of $1.9 \mathrm{~m}^{2} \mathrm{~g}^{-1}$, the calcification rates are: $G$. bulloides $\left(3.0 \times 10^{-9}\right)<$ G. sacculifer $\left(3.3 \times 10^{-9}\right)<$ G. ruber $\left(8.6 \times 10^{-9}\right)<$ O. universa $\left(1.3 \times 10^{-8}\right)$. Applying species-specific values of 1.2 and $2.0 \mathrm{~m} \mathrm{~m}^{2} \mathrm{~g}^{-1}$ to the $O$. universa and G. sacculifer data, respectively (de Kanel and Morse, 1979), lowers the mean O. universa value by $\sim 40 \%$ to $8.3 \times 10^{-9}$ and raises the mean $G$. sacculifer value by $\sim 5 \%$ to $3.5 \times 10^{-9}$ $\mathrm{mol} \mathrm{m} \mathrm{s}^{-1}$, but this does not alter the major patterns observed (Fig. S2).

Response of calcification rate ( $\mu \mathrm{g} / \mathrm{day})$ to experimental parameters (temperature, salinity, $\left[\mathrm{CO}_{3}{ }^{2-}\right]$ ) varies within and among species (Table S1). Calcification rate increases with $\left[\mathrm{CO}_{3}{ }^{2-}\right]$ in $\mathrm{pH}$ and DIC experiments with G. sacculifer $(\mathrm{p}=0.004$ and 0.003 , respectively), and decreases slightly with salinity in G. sacculifer $(\mathrm{p}=0.02)$. Other linear regressions are not significant at a $95 \%$ confidence level $(\mathrm{p} \leq 0.05)$. Calcification rate in $O$. universa increases with temperature $(\mathrm{p}=0.08)$ and appears to peak at $\mathrm{pH} 8.3$ (total scale) $\left(\sim 300 \mu \mathrm{mol} / \mathrm{kg}\left[\mathrm{CO}_{3}{ }^{2-}\right]\right)$ and at a salinity of $\sim 33$ (Fig. 9). Significance of trends in G. bulloides was not assessed due to paucity of data ( $\mathrm{n}=2$ in each experiment).

\section{$\mathrm{Sr} / \mathrm{Ca}$}

$\mathrm{Sr} / \mathrm{Ca}$ increased with $\mathrm{pH}$ in all three species: O. universa $(\mathrm{R}=0.93, \mathrm{p}=0.02)$, G. ruber $(\mathrm{R}=0.99, \mathrm{p}=0.06)$, and G. sacculifer $(\mathrm{R}=0.83, \mathrm{p}=0.08)$ (calculated using individual points, not averages). In G. sacculifer, when $\left[\mathrm{CO}_{3}^{2-}\right]$ is raised by increasing $\mathrm{pH}, \mathrm{Sr} / \mathrm{Ca}$ only increases by $0.016 \mathrm{mmol} / \mathrm{mol}$ per $100 \mu \mathrm{mol} / \mathrm{kg} \mathrm{CO}_{3}{ }^{2-}(\mathrm{R}=0.77, \mathrm{p}=0.12)$, but when $\left[\mathrm{CO}_{3}{ }^{2-}\right]$ is raised by increasing DIC and holding $\mathrm{pH}$ constant, $\mathrm{Sr} / \mathrm{Ca}$ increases by 0.19 $\mathrm{mmol} / \mathrm{mol}$ per $100 \mu \mathrm{mol} / \mathrm{kg} \mathrm{CO}_{3}{ }^{2-}(\mathrm{R}=0.88, \mathrm{p}=0.12)$ (Figs. 1 and 2$)$. This strong effect of DIC manifests as more than a doubling of $\mathrm{Sr} / \mathrm{Ca}$ from 0.74 to $1.6 \mathrm{mmol} / \mathrm{mol}$ with an increase in DIC from $\sim 1150$ to $4195 \mu \mathrm{mol} / \mathrm{kg}$. The sensitivity of $\mathrm{Sr} / \mathrm{Ca}$ to $\mathrm{CO}_{3}{ }^{2-}$ is not constant across the experimental DIC range: below the ambient DIC of $\sim 2000 \mu \mathrm{mol} / \mathrm{kg}$, it is $\sim 62 \%$ per $100 \mu \mathrm{mol} / \mathrm{kg} \mathrm{CO}_{3}{ }^{2}$, while above $\sim 2000 \mu \mathrm{mol} / \mathrm{kg}$ it drops to $\sim 8 \%$ per 100 $\mu \mathrm{mol} / \mathrm{kg} \mathrm{CO}{ }_{3}{ }^{2}$ (Fig. 2). In O. universa, when $\left[\mathrm{CO}_{3}{ }^{2-}\right]$ is raised by increasing DIC (holding $\mathrm{pH}$ constant), the $\mathrm{Sr} / \mathrm{Ca}$ increase is constant across the experimental range at $0.12 \mathrm{mmol} / \mathrm{mol}$ per $100 \mu \mathrm{mol} / \mathrm{kg} \mathrm{CO}_{3}{ }^{2-}(\mathrm{R}=0.96, \mathrm{p}<0.01)$ (Fig. 2$) . \mathrm{Sr} / \mathrm{Ca}$ does not exhibit significant relationships $(\mathrm{p}<0.05)$ with temperature or salinity in any single species (Table 1). When all species data are combined, there is a positive correlation with temperature $(\mathrm{R}=0.61, \mathrm{p}=0.03)$ and salinity $(\mathrm{R}=0.51, \mathrm{p}=0.06)$. Sr/Ca responds linearly to changes in solution $\mathrm{Sr} / \mathrm{Ca}$ (Fig. 3).

503 
504 In $O$. universa, $\mathrm{Cd} / \mathrm{Ca}$ increases as temperature rises $(\mathrm{R}=0.91, \mathrm{p}=0.03) . \mathrm{Cd} / \mathrm{Ca}$ is 505 negatively correlated with salinity, $\mathrm{pH}$, and $\left[\mathrm{CO}_{3}{ }^{2-}\right]$ (Fig. 4), but the correlations are not 506 significant $(\mathrm{p}=0.34,0.24$, and 0.48 , respectively).

507

508

509

510

511

512

513

514

515

516

517

518

519

520

521

522

523

524

525

526

527

528

529

530

531

532

533

534

535

536

537

538

539

540

541

542

543

544

545

546

547

$\mathrm{Mn} / \mathrm{Ca}$

In O. universa, $\mathrm{Mn} / \mathrm{Ca}$ decreases with salinity $(\mathrm{R}=-0.78, \mathrm{p}=0.04)$, temperature $(\mathrm{R}=-$ $0.80, \mathrm{p}=0.10), \mathrm{pH}(\mathrm{R}=-0.95, \mathrm{p}=0.01)$, and $\left[\mathrm{CO}_{3}{ }^{2-}\right](\mathrm{R}=-0.95, \mathrm{p}=0.02)$ (Figs. 1 and $4)$.

\section{$\mathrm{Mg} / \mathrm{Ca}$}

$\mathrm{Mg} / \mathrm{Ca}$-salinity relationships for $O$. universa, G. ruber, and G. sacculifer are reported in Hönisch et al. (2013). In G. sacculifer, $\mathrm{Mg} / \mathrm{Ca}$ increases with DIC according to the following relationship: $\mathrm{Mg} / \mathrm{Ca}=\mathrm{DIC}^{*} 1.5^{*} 10^{-4}\left( \pm 1.4^{*} 10^{-4}\right)+3.5( \pm 0.4)( \pm 95 \%$ confidence bounds, $\mathrm{n}=4)$. The same $\mathrm{Mg} / \mathrm{Ca}$ data regressed against $\left[\mathrm{CO}_{3}{ }^{2-}\right]$ in DIC experiments yield $\mathrm{Mg} / \mathrm{Ca}=\left[\mathrm{CO}_{3}{ }^{2-}\right]^{*} 1.2^{*} 10^{-3}\left( \pm 1.1 * 10^{-3}\right)+3.5( \pm 0.3)$. In contrast, in $\mathrm{pH}$ experiments with G. sacculifer $\mathrm{Mg} / \mathrm{Ca}$ decreases slightly $(\sim 0.2 \mathrm{mmol} / \mathrm{mol})$ between $\sim 200$ and $500 \mu \mathrm{mol} / \mathrm{kg}\left[\mathrm{CO}_{3}{ }^{2-}\right] . \mathrm{Mg} / \mathrm{Ca}$ decreases more strongly with $\left[\mathrm{CO}_{3}{ }^{2-}\right]$ in G. ruber, $O$. universa, and G. bulloides (Fig. 4).

In all species cultured, $\mathrm{Mg} / \mathrm{Ca}$ increases with temperature (Table $\mathrm{S} 1$ ). Temperature calibrations for O. universa and G. bulloides cultured in the year 2000 were reported in Russell et al. (2004). Exponential fits of the form $\mathrm{Mg} / \mathrm{Ca}=\mathrm{B} \exp (\mathrm{AT})$, where $\mathrm{T}$ is temperature, yield $\mathrm{B}=0.78( \pm 0.52)$ and $\mathrm{A}=0.062( \pm 0.025)$ for $G$. sacculifer $(\mathrm{n}=4)$. With only $\mathrm{n}=3$, our $G$. ruber (pink) data result in uncertainties several times larger than the fit parameters themselves $(\mathrm{B}=1( \pm 9)$ and $\mathrm{A}=0.053( \pm 0.29))$. When combined with $\mathrm{Mg} / \mathrm{Ca}$ data from Kisakürek et al. (2008) ( $\mathrm{n}=8$ total), the fit constants for $G$. ruber are B $=0.55( \pm 0.33)$ and $\mathrm{A}=0.080( \pm 0.022)$.

\section{$\mathrm{U} / \mathrm{Ca}$}

In $O$. universa, $\mathrm{U} / \mathrm{Ca}$ decreases with $\left[\mathrm{CO}_{3}{ }^{2-}\right](\mathrm{R}=-0.93, \mathrm{p}=0.02), \mathrm{pH}(\mathrm{R}=-0.98, \mathrm{p}=$ $0.003)$, salinity $(R=-0.74, p=0.06)$, and temperature $(R=-0.95, p=0.01)$ (Fig. 5).

\section{$\mathrm{Li} / \mathrm{Ca}$}

$\mathrm{Li} / \mathrm{Ca}$ does not exhibit significant relationships with any parameters in any foraminifer species. Li/Ca of G. ruber (pink) in the lowest temperature experiment was anomalously high (Table S1, Fig. 6).

548

$\mathrm{Na} / \mathrm{Ca}$

In G. ruber (pink), $\mathrm{Na} / \mathrm{Ca}$ increases with salinity $(\mathrm{Na} / \mathrm{Ca}=0.074( \pm 0.006) * \mathrm{~S}+4.1( \pm 0.2)$ $( \pm 95 \% \mathrm{CI}) ; \mathrm{R}=0.99, \mathrm{p}=0.01)$. Correlations with temperature, salinity and $\left[\mathrm{CO}_{3}{ }^{2-}\right]$ are 
not significant. In G. sacculifer, no significant relationships are observed (Table 1, Fig. 7).

551

\section{$\mathrm{Ba} / \mathrm{Ca}$ and $\mathrm{B} / \mathrm{Ca}$}

$\mathrm{Ba} / \mathrm{Ca}$ and $\mathrm{B} / \mathrm{Ca}$ results have been reported in Hönisch et al. (2011) and Allen et al. (2012), respectively, and the primary relationships with environmental parameters are not duplicated here.

\section{Correlations among trace elements}

In the following section, only Pearson correlation coefficients (R) with $p$ values $\leq 0.10$ ( $\geq$ $90 \%$ confidence) are discussed unless otherwise noted. Data used to determine correlations are restricted to foraminifers grown in "normal" (i.e. modern) seawater; Paleocene seawater experiments conducted in 2013 are excluded from this analysis. For a full list of correlations and $\mathrm{p}$ values, see Table S2, and for a text description, see Section 3 of SOM.

\section{Discussion}

\section{$4.1 \mathrm{Sr} / \mathrm{Ca}$}

$\mathrm{Sr} / \mathrm{Ca}$ ratios of foraminiferal samples grown at ambient conditions fall within the range reported by previous studies (Fig. 1) and the calculated $D_{\mathrm{Sr}}$ of 0.16 for our samples $\left(\mathrm{D}_{\mathrm{Sr}}\right.$ $\left.=[\mathrm{Sr} / \mathrm{Ca}]_{\text {calcite }} /[\mathrm{Sr} / \mathrm{Ca}]_{\text {seawater }}\right)$ is also consistent with previous culture experiments and core top studies $\left(\mathrm{D}_{\mathrm{Sr}}=0.16\right.$, Delaney and Bé, 1985; Dueñas-Bohórquez et al., 2009; Emiliani, 1955; Lea et al., 1999b; Russell et al., 2004). In addition, comparison of our modern $\left(\mathrm{Sr} / \mathrm{Ca}_{\text {Seawater }}=8.5 \mathrm{mmol} / \mathrm{mol}\right)$ and Paleocene seawater experiments $(\mathrm{Sr} / \mathrm{Ca}$ Seawater $=4.5$ $\mathrm{mmol} / \mathrm{mol}$ ) confirms that $\mathrm{Sr} / \mathrm{Ca}$ of foraminiferal calcite increases linearly with $\mathrm{Sr} / \mathrm{Ca}$ of seawater $\left(\mathrm{Sr} / \mathrm{Ca}_{\mathrm{Foram}}=0.16 * \mathrm{Sr} / \mathrm{Ca}_{\text {Seawater }}\right.$, Fig. 3).

Kisakürek et al. (2008) reported $\mathrm{Sr} / \mathrm{Ca}$ increasing with salinity at a rate of $0.02 \mathrm{mmol} / \mathrm{mol}$ per salinity unit $\left(\mathrm{R}^{2}=0.81, \mathrm{p}=0.10\right)$, and Lea et al. (1999) also reported a positive $\mathrm{Sr} / \mathrm{Ca}$-salinity relationship. Single-species calibrations from our study do not yield significant relationships between $\mathrm{Sr} / \mathrm{Ca}$ and salinity or $\mathrm{Sr} / \mathrm{Ca}$ and temperature (Table 1). When all species data are combined, positive relationships with salinity and temperature are observed $(\mathrm{p}=0.03$ and 0.06 , respectively). However, minor species-specific differences in $\mathrm{Sr}$ incorporation could be partly responsible - G. ruber typically has higher $\mathrm{Sr} / \mathrm{Ca}$ than G. bulloides at any given condition, and G. ruber experiments cover the upper end of the temperature range - so we do not consider these combined-species observations to provide convincing evidence of a positive $\mathrm{Sr} / \mathrm{Ca}$-temperature or $\mathrm{Sr} / \mathrm{Ca}$ salinity relationship.

A small but significant increase in $\mathrm{Sr} / \mathrm{Ca}$ is observed with increasing $\mathrm{pH}$. Given a glacialinterglacial surface ocean $\mathrm{pH}$ shift of 0.15 units (Hönisch and Hemming, 2005; Henehan et al., 2013), the $\mathrm{Sr} / \mathrm{Ca}$ shift in $G$. sacculifer would amount to a $\sim 0.01 \mathrm{mmol} / \mathrm{mol}$ change. 
Assuming a glacial-interglacial surface ocean shift of $\sim 100 \mu \mathrm{mol} / \mathrm{kg}\left[\mathrm{CO}_{3}{ }^{2-}\right]$, the results from the $\mathrm{pH}$ experiments predict a $\mathrm{Sr} / \mathrm{Ca}$ increase of $\sim 0.014 \mathrm{mmol} / \mathrm{mol}$. With an analytical RSD of $4 \%$, such changes would be undetectable.

To date, DIC experiments have only been performed with G. sacculifer and O. universa. In the DIC experiments, where $\left[\mathrm{CO}_{3}{ }^{2-}\right]$ variation is linked to DIC instead of $\mathrm{pH}$, the sensitivity of $\mathrm{Sr} / \mathrm{Ca}$ to $\left[\mathrm{CO}_{3}{ }^{2-}\right]$ in G. sacculifer is $12 \mathrm{x}$ higher than the sensitivity observed in $\mathrm{pH}$ experiments (calculated as the ratio of the $[\mathrm{Sr} / \mathrm{Ca}] /\left[\mathrm{CO}_{3}{ }^{2-}\right]$ slopes for DIC and $\mathrm{pH}$ experiments, $1.9 \mu \mathrm{mol} / \mathrm{mol}$ per $\mu \mathrm{mol} / \mathrm{kg} / 0.16 \mu \mathrm{mol} / \mathrm{mol}$ per $\mu \mathrm{mol} / \mathrm{kg} \approx 12$; Fig. 2 and Table S1). Why does $\mathrm{Sr} / \mathrm{Ca}$ respond so differently to $\left[\mathrm{CO}_{3}{ }^{2-}\right]$ depending on whether $\mathrm{pH}$ or DIC is changing?

Incorporation of $\mathrm{Sr}$ into calcite increases with calcification rate (Gabitov and Watson, 2006; Lorens, 1981), and can be accurately simulated by diffusion-growth models in which Sr incorporation is a function of two competing processes: calcite growth rate and the rate of solution-surface molecular exchange (DePaolo, 2011). Our two different carbonate system experiments ( $\mathrm{pH}$ and DIC) span similar calcite saturation states from $\Omega$ $\approx 2$ to 12 (where $\Omega=\left(\left[\mathrm{Ca}^{2+}\right]\left[\mathrm{CO}_{3}{ }^{2-}\right]\right)_{\text {in }}$ situ $\left./\left[\mathrm{Ca}^{2+}\right]\left[\mathrm{CO}_{3}{ }^{2-}\right]\right)_{\text {saturation }}$ ). If foraminiferal calcification rate simply increased with $\Omega$, this factor alone could not explain the observed $\mathrm{Sr} / \mathrm{Ca}$ behavior. On the other hand, if calcification rate is a function of $\Omega$ as well as $\mathrm{pH}$ and the relative proportions of $\mathrm{Ca}^{2+}$ and $\mathrm{CO}_{3}{ }^{2-}$ in solution, as in inorganic experiments (Nehrke et al., 2007; Wolthers et al., 2012), this may help explain our observations. The G. sacculifer DIC experiment data parallel inorganic calcites grown by Nehrke et al. (2007) on a $\mathrm{D}_{\mathrm{Sr}}$ vs. $\left[\mathrm{CO}_{3}{ }^{2-}\right] /\left[\mathrm{Ca}^{2+}\right]$ plot (Fig. 10). This suggests that, as for inorganic precipitation, foraminiferal calcification rate may increase as $\left[\mathrm{CO}_{3}{ }^{2-}\right] /\left[\mathrm{Ca}^{2+}\right]$ approaches 1, with $\mathrm{D}_{\mathrm{Sr}}$ and therefore $\mathrm{Sr} / \mathrm{Ca}$ increasing as calcification rate increases. Accordingly, one might speculate that the difference between our DIC and $\mathrm{pH}$ experiments reflects a $\left[\mathrm{CO}_{3}{ }^{2-}\right] /\left[\mathrm{Ca}^{2+}\right]$-driven rate influence on $\mathrm{Sr}$ incorporation.

Experiments with benthic foraminifera indicate that some species have the ability to vacuolize seawater and then increase its $\mathrm{pH}$ to values of 9 or greater, increasing the calcite saturation state and promoting calcite precipitation (Bentov et al., 2009; de Nooijer et al., 2014). Given this scenario, when foraminifers vacuolize high DIC seawater and raise the vacuole $\mathrm{pH}$, they are able to drive the solution $\left[\mathrm{CO}_{3}{ }^{2-}\right] /\left[\mathrm{Ca}^{2+}\right]$ closer to 1 and generate faster precipitation rates and greater $\mathrm{Sr}$ incorporation. Foraminifers could also raise the $\mathrm{pH}$ of low DIC seawater to the same level, but this would produce a smaller $\left[\mathrm{CO}_{3}{ }^{2-}\right] /\left[\mathrm{Ca}^{2+}\right]$ because there is less DIC and thus less $\mathrm{HCO}_{3}{ }^{-}$available to convert to $\mathrm{CO}_{3}{ }^{2-}$ .

Model vacuole compositions based on this thought experiment are illustrated in Fig. 10 (black triangles), along with measured $\mathrm{Sr} / \mathrm{Ca}$ and $\left[\mathrm{CO}_{3}{ }^{2-}\right] /\left[\mathrm{Ca}^{2+}\right]$ values for the experimental seawater in which foraminifera were grown (filled circles). Vacuole compositions were calculated by increasing initial experimental seawater $\mathrm{pH}$ to 9 (total scale) and assuming $[\mathrm{Ca}]_{\mathrm{sw}}=10 \mathrm{mmol} / \mathrm{kg}$ for the modern seawater experiments. Plotting observed $\mathrm{Sr} / \mathrm{Ca}$ against seawater vacuole $\left[\mathrm{CO}_{3}{ }^{2-}\right] /\left[\mathrm{Ca}^{2+}\right]$ values at $\mathrm{pH}=9$ results in alignment of the data roughly parallel to the inorganic calcite $\mathrm{Sr} / \mathrm{Ca}-\left[\mathrm{CO}_{3}{ }^{2-}\right] /\left[\mathrm{Ca}^{2+}\right]$ 
641 relationship observed by Nehrke et al. (2007), which is consistent with the idea that 642 calcification rate is influenced by $\left[\mathrm{CO}_{3}{ }^{2-}\right] /\left[\mathrm{Ca}^{2+}\right]$ and $\mathrm{Sr} / \mathrm{Ca}$ increases with calcification 643 rate.

644

Rates of calcification are notoriously difficult to measure in foraminifera. In this study, we provide approximations of net average calcification rates for each experiment (Table $\mathrm{S} 1)$. Average $G$. sacculifer calcification rates from the $\mathrm{pH}$ and DIC experiments increase consistently as seawater $\left[\mathrm{CO}_{3}{ }^{2-}\right]$ increases (Fig. 9), which supports the rate-controlled $\mathrm{Sr}$ incorporation scenario posited above. However, $\mathrm{D}_{\mathrm{Sr}}$ values do not increase consistently with average calcification rates (Fig. 11). Potential explanations for this discrepancy include: 1) If foraminifera calcify episodically (i.e., in short bursts of growth), then our net calcification rates, which were calculated assuming continuous growth, do not accurately represent the true, instantaneous calcification rates, or 2) $D_{S r}$ is not ratecontrolled. In the latter case, it is possible that another factor is at work, perhaps variation in the availability of free $\mathrm{Sr}$ or $\mathrm{Ca}$ ions. Calculation of dissolved metal speciation is beyond the scope of the present study, but dissolved ion speciation and availability may vary with the presence of certain organic ligands and with the major composition of seawater (Stumm and Morgan, 1996). At the moment, we can not yet definitively confirm or rule out a calcification rate effect on $\mathrm{Sr} / \mathrm{Ca}$ with the available data.

660

661

662

663

664

665

666

667

668

669

670

671

672

673

674

675

676

677

678

679

680

681

682

683

684

It is interesting to note that, with the exception of the lowest-DIC experiment, $O$. universa $\mathrm{Sr} / \mathrm{Ca}$ results also converge on the same trend-line as $G$. sacculifer when the above model is applied (internal $\mathrm{pH}=9$, Fig. 10, gray diamonds). The two sets of DIC experiments ( $G$. sacculifer and $O$. universa) have similar slopes but are offset from each other when plotted against $\left[\mathrm{CO}_{3}{ }^{2-}\right] /\left[\mathrm{Ca}^{2+}\right]$ (Fig. 10). This offset could be due to: 1 ) lower average $\mathrm{pH}$ of $O$. universa experiments, perhaps leading to greater $\mathrm{HCO}_{3}{ }^{-}$involvement in calcification, causing rates to be maximized at lower solution $\left[\mathrm{CO}_{3}{ }^{2-}\right] /\left[\mathrm{Ca}^{2+}\right]$ ratios (as observed for inorganic calcites by Wolthers et al. (2012), 2) higher average calcification rates in $O$. universa experiments (Fig. 8) leading to greater $\mathrm{Sr}$ incorporation than in $G$. sacculifer, or 3) differences in major element composition of experimental seawater between studies (Catalina 2013 experiments with O. universa were conducted in model Paleocene seawater with $\mathrm{Mg} \approx 30 \mathrm{mmol} / \mathrm{kg}$ and $\mathrm{Ca} \approx 20 \mathrm{mmol} / \mathrm{kg}$, whereas Puerto Rico 2010 experiments with $G$. sacculifer used ambient seawater, with $\mathrm{Mg} \approx 50 \mathrm{mmol} / \mathrm{kg}$ and $\mathrm{Ca} \approx 10 \mathrm{mmol} / \mathrm{kg})$.

685

The behavior of $\mathrm{Sr} / \mathrm{Ca}$ in the constant-pH, variable-DIC experiments is intriguing, and if other proxies can be used to estimate another carbonate system variable (e.g., $\delta^{11} \mathrm{~B}$ for $\mathrm{pH}), \mathrm{Sr} / \mathrm{Ca}$ might prove useful for constraining the seawater carbonate system. Given the possibility of a rate influence on $\mathrm{Sr} / \mathrm{Ca}$ partitioning, it will be important to gather additional calcification rate data (preferably with higher temporal resolution, e.g., hourly measurements) and to evaluate the extent of other, independent influences on calcification rate such as light and food availability.

\section{2 $\mathrm{Mn} / \mathrm{Ca}$ and $\mathrm{Cd} / \mathrm{Ca}$}


Mn and Cd may be influenced by similar mechanisms during calcite growth as they share the same ionic charge (+2), have similar effective ionic radii, are highly compatible (D > 1), and both substitute for Ca in the calcite lattice (Lorens, 1981; Reeder, 1996; Wartel et al., 1991). Experiments with inorganic calcite have revealed decreasing $\mathrm{Mn} / \mathrm{Ca}$ and $\mathrm{Cd} / \mathrm{Ca}$ with increasing calcite growth rate (Lorens, 1981). If foraminiferal calcification rates increase as $\mathrm{pH}$ and $\left[\mathrm{CO}_{3}{ }^{2-}\right]$ increase, then the more energetically-demanding dehydration and incorporation of smaller ions might be expected to increasingly exclude $\mathrm{Mn}$ and Cd during more rapid calcite growth (DePaolo, 2011). Another possible kinetic mechanism is described by an alternative growth entrapment model in which element incorporation (or entrapment) in the bulk crystal lattice depends on the competing factors of growth rate and ion diffusivity within the mineral surface layer (Watson, 2004). Either of these kinetic mechanisms could play a role in our observed decreases in $\mathrm{Mn}$ and $\mathrm{Cd}$ incorporation at higher $\mathrm{pH}$ and $\left[\mathrm{CO}_{3}^{2-}\right]$ (Fig. 4).

In culture experiments, G. bulloides consistently has higher $\mathrm{Mn} / \mathrm{Ca}$ and $\mathrm{Cd} / \mathrm{Ca}$ than $O$. universa. Mashiotta et al. (1997) offered two possible explanations for the $\mathrm{Cd} / \mathrm{Ca}$ difference: 1) G. bulloides calcifies more slowly than $O$. universa due to its lack of symbionts and correspondingly lower-saturation microenvironment, leading to higher $\mathrm{Cd} / \mathrm{Ca}$ for kinetic reasons (discussed above) or 2) the dinoflagellate symbionts borne by $O$. universa remove $\mathrm{Cd}$ directly from solution during photosynthesis, lowering the concentration of $\mathrm{Cd}$ in the microenvironment and leading to lower $\mathrm{Cd} / \mathrm{Ca}$ of the shell. If symbionts also remove $\mathrm{Mn}$ from the microenvironment, this might explain the consistent $\mathrm{Mn} / \mathrm{Ca}$ and $\mathrm{Cd} / \mathrm{Ca}$ offset between species. It is not known whether foraminifera or their symbionts actively take up $\mathrm{Mn}$, but in some algae $\mathrm{Mn}$ is used as a cofactor in metalloenzymes (Sunda, 1989).

Average net calcification rates do increase with $\left[\mathrm{CO}_{3}{ }^{2-}\right]$ in both $G$. bulloides and $O$. universa experiments (Fig. 9), consistent with a rate control. Calcification rates in $O$. universa experiments are also 5-6 $\mu \mathrm{g} /$ day higher than G. bulloides experiments on average, providing additional support for the idea that higher calcification rates lead to lower $\mathrm{Mn} / \mathrm{Ca}$ and $\mathrm{Cd} / \mathrm{Ca}$. However, it appears that there may be a calcification rate maximum at $\sim 300 \mu \mathrm{mol} / \mathrm{kg}\left[\mathrm{CO}_{3}{ }^{2-}\right]$ in $O$. universa, which is inconsistent with a calcification rate control on the continuous decline in $\mathrm{Mn}$ and $\mathrm{Cd}$ incorporation. This possibility is difficult to assess since $O$. universa calcification rates are so variable (see $1 \sigma$ error bars in Fig. 8). Symbiont activity could well be an additional or alternative control. Low light experiments at high saturation state (high $\left[\mathrm{CO}_{3}{ }^{2-}\right]$ and/or $\left[\mathrm{Ca}^{2+}\right]$ ) might allow us to disentangle the two parameters, if calcification rates can be closely monitored.

The influence of temperature on $\mathrm{Cd}$ and $\mathrm{Mn}$ incorporation in calcite can be predicted from thermodynamic principles, assuming equilibrium conditions and applying the Van't Hoff equation to the equilibrium constants (Haynes, 2014). Such calculations predict a slight decrease in $\mathrm{Cd} / \mathrm{Ca}$ and $\mathrm{Mn} / \mathrm{Ca}$ with temperature (Fig. S1). However, in $O$. universa, $\mathrm{Mn} / \mathrm{Ca}$ decreases with temperature $(\mathrm{R}=-0.8, \quad \mathrm{p}=0.10)$ while $\mathrm{Cd} / \mathrm{Ca}$ increases with temperature $(\mathrm{R}=0.91, \mathrm{p}=0.03)$, defying theoretical predictions. Additional discussion of theoretical vs. observed partitioning is presented in section 4.8. 
The use of $\mathrm{Mg} / \mathrm{Ca}$ as a temperature proxy has been extensively discussed in the literature, and a portion of our results have already been published in Hönisch et al. (2013). Our temperature results are broadly consistent with previous calibrations and thus increase confidence in existing relationships. For this comparison we only consider data from studies that employed a strong oxidation step in the cleaning procedure $\left(\mathrm{H}_{2} \mathrm{O}_{2}\right.$ of $30 \%$ or greater), since this step results in $\mathrm{Mg} / \mathrm{Ca}$ values that can differ significantly from previous techniques with weaker oxidation (Russell et al., 2004). Our G. sacculifer temperature sensitivity (7.8\%) is closer to the "with sac" sediment-trap calibration of Anand et al. (2003) than the "without-sac" calibration $\left(6.9 \%\right.$ versus $4.8 \%$ increase in $\mathrm{Mg} / \mathrm{Ca}$ per ${ }^{\circ} \mathrm{C}$, respectively). In our high-pH experiment, several final "sac" chambers were amputated and analyzed separately $(\mathrm{n}=12)$, yielding a lower $\mathrm{Mg} / \mathrm{Ca}$ value than non-sac chambers $(3.3 \pm 0.1$ and $3.6 \pm 0.1 \mathrm{mmol} / \mathrm{mol}$, respectively). It is possible that differences in growth habit or mechanism between sac and non-sac chambers may explain some of the difference between the with- and without-sac calibrations.

Data from two of our three G. ruber (pink) $\mathrm{Mg} / \mathrm{Ca}$ temperature experiments overlap with the core-top calibration of Anand et al. (2003) within analytical error. The exponential fit parameters for the G. ruber (pink) culture data have wide $95 \%$ confidence envelopes, encompassing all previous core-top and culture calibrations with G. ruber (white) (Kısakürek et al., 2008). Orbulina universa $\mathrm{Mg} / \mathrm{Ca}$ data are consistent with the calibration of Russell et al. (2004), which has a higher pre-exponential constant (higher $\mathrm{Mg} / \mathrm{Ca}$ values, on average) than the Sargasso Sea sediment trap study by Anand et al. (2003). In short, results from our culture experiments are consistent with earlier sediment trap and culture $\mathrm{Mg} / \mathrm{Ca}$-temperature calibrations (Figs. 1 and 4), with the exception of the $O$. universa sediment trap calibration (Anand et al., 2003). The influence of salinity on $\mathrm{Mg} / \mathrm{Ca}$ is minor compared to that of temperature; recommended $\mathrm{Mg} / \mathrm{Ca}$-salinity calibrations can be found in Hönisch et al. (2013).

In $\mathrm{pH}$ experiments, $\mathrm{Mg} / \mathrm{Ca}$ of $O$. universa and G. bulloides increases with decreasing $\left[\mathrm{CO}_{3}{ }^{2-}\right]$ below a threshold of $\sim 200 \mu \mathrm{mol} / \mathrm{kg}\left[\mathrm{CO}_{3}{ }^{2-}\right]$ (Fig. 4), largely consistent with previous work (Russell et al., 2004). The $\mathrm{Mg} / \mathrm{Ca}$ value from our highest-pH experiment with $O$. universa $\left(\left[\mathrm{CO}_{3}{ }^{2-}\right]=581 \mu \mathrm{mol} / \mathrm{kg}\right)$ falls lower than all other values at lower $\left[\mathrm{CO}_{3}{ }^{2-}\right.$ ], hinting at non-linear behavior, perhaps a second inflection point or a continuous linear response of $\mathrm{Mg} / \mathrm{Ca}$ to $\left[\mathrm{CO}_{3}{ }^{2-}\right]$ as suggested by Evans et al. (2016). $\mathrm{Mg} / \mathrm{Ca}$ of G. ruber (pink) is also higher at lower $\left[\mathrm{CO}_{3}{ }^{2-}\right]$, similar to the G. ruber (white) results of Kisakürek et al. (2008), though the trend in G. ruber (pink) is not significant at a $95 \%$ confidence level and neither is the trend in G. sacculifer (Table 1). A calcification rate control on $\mathrm{Mg}$ incorporation is one possible explanation for the species that do exhibit an $\mathrm{Mg} / \mathrm{Ca}$ response to the carbonate system, perhaps with faster calcification rates at higher $\left[\mathrm{CO}_{3}{ }^{2-}\right]$ leading to greater $\mathrm{Mg}$ exclusion. Such a trend could be explained by either of the growth entrapment models discussed above in 4.2 (Watson, 2004; DePaolo, 2011). Net calcification rates for $O$. universa support the idea of a rate control on $\mathrm{Mg}$ incorporation, with rates increasing rapidly until $\sim 200-300 \mu \mathrm{mol} / \mathrm{kg}$ and then leveling out (Fig. 9). 
778

779

780

781

782

783

784

785

786

787

788

789

790

791

792

793

794

795

796

797

798

799

800

801

802

803

804

805

806

807

808

809

810

811

812

813

814

815

816

817

818

819

820

821

822

823

However, calcification rate data from other species do not increase detectably with $\left[\mathrm{CO}_{3}{ }^{2-}\right.$ ] and/or do not exhibit any kind of threshold behavior. Also, contrary to expectations described above, the fast-growing $O$. universa is characterized by higher $\mathrm{Mg} / \mathrm{Ca}$ than the slow-growing G. bulloides, on average. An additional complication for the $\left[\mathrm{CO}_{3}{ }^{2-}\right]$-driven rate control suggested above is the discrepancy between $\mathrm{Mg} / \mathrm{Ca}-\left[\mathrm{CO}_{3}{ }^{2-}\right]$ relationships determined in $\mathrm{pH}$ and DIC experiments, discussed below.

In G. sacculifer, $\mathrm{Mg} / \mathrm{Ca}$ increases with DIC (and also $\left[\mathrm{CO}_{2}\right],\left[\mathrm{CO}_{3}{ }^{2-}\right]$ and $\left[\mathrm{HCO}_{3}{ }^{2-}\right]$ ) in constant-pH, variable-DIC experiments (Table 1, Fig. 12). In these experiments, $\mathrm{Mg} / \mathrm{Ca}$ increases with $\left[\mathrm{CO}_{3}{ }^{2-}\right]$, in contrast to the insignificant response to $\left[\mathrm{CO}_{3}{ }^{2-}\right]$ observed in $\mathrm{pH}$ experiments (Fig. 4). This contrasting behavior suggests that $\left[\mathrm{CO}_{3}{ }^{2-}\right]$ (or $\mathrm{pH}$ ) can not be the only carbonate system parameter that exerts control on $\mathrm{Mg} / \mathrm{Ca}$. In Figure $12 \mathrm{~B}$, the highest $\mathrm{pH}$ and highest DIC experiments are characterized by similar $\left[\mathrm{CO}_{3}{ }^{2-}\right]$ values $(\sim 500 \mu \mathrm{mol} / \mathrm{kg}$ ) but very different $\mathrm{Mg} / \mathrm{Ca}$ values ( 3.6 and $4.1 \mathrm{mmol} / \mathrm{mol}$, respectively). These results indicate that neither $\left[\mathrm{CO}_{3}{ }^{2-}\right]$, DIC, nor calcification rate can consistently explain all of the G. sacculifer $\mathrm{Mg} / \mathrm{Ca}$ data.

What kind of effect might this have on G. sacculifer paleo-temperature records, if DIC is indeed influencing $\mathrm{Mg} / \mathrm{Ca}$ ? Applying our calibrations to estimated changes across Pleistocene ice age cycles (calculated assuming glacial-interglacial differences of $-4^{\circ} \mathrm{C}$, +1 salinity unit, $+100 \mu \mathrm{mol} / \mathrm{kg}\left[\mathrm{CO}_{3}{ }^{2-}\right]$ or $+100 \mu \mathrm{mol} / \mathrm{kg}$ DIC), the predicted influence of DIC is $\sim 0.015 \mathrm{mmol} / \mathrm{mol}$, which is very small compared to the temperature effect of 0.8 $\mathrm{mmol} / \mathrm{mol}$. The predicted impact of salinity $(0.2 \mathrm{mmol} / \mathrm{mol})$ is $\sim 10 \mathrm{x}$ larger than that of DIC, and has more potential to impact paleo-temperature estimates (e.g., Khider et al., 2014). Altogether, our calibrations predict a glacial-interglacial $\mathrm{Mg} / \mathrm{Ca}$ change of 0.6 $\mathrm{mmol} / \mathrm{mol}$ if salinity and DIC effects are taken into account. Does $\left[\mathrm{CO}_{3}{ }^{2-}\right]$ influence $\mathrm{Mg} / \mathrm{Ca}$ observed in $\mathrm{pH}$ experiments? Some previous work indicates that the carbonate ion effect is only active below $\sim 200 \mu \mathrm{mol} / \mathrm{kg}\left[\mathrm{CO}_{3}{ }^{2-}\right]$ (Russell et al., 2004), while other results suggest that the effect may be felt across a much wider $\left[\mathrm{CO}_{3}{ }^{2-}\right]$ range (Evans et al., 2016). More experiments are needed to resolve specific controls (DIC vs. pH vs $\left[\mathrm{CO}_{3}{ }^{2-}\right.$ ) and the shape of their $\mathrm{Mg} / \mathrm{Ca}$ response (linear, nonlinear, etc.).

In summary, any carbonate system effects on $\mathrm{Mg} / \mathrm{Ca}$ in $\mathrm{G}$. sacculifer are expected to be within analytical error for most late Pleistocene records. The influence of DIC would constitute $\sim 2 \%$ of the $\mathrm{Mg} / \mathrm{Ca}$ signal across a $4^{\circ} \mathrm{C}$ temperature change according to the $G$. sacculifer $\mathrm{Mg} / \mathrm{Ca}$-DIC relationship (reported in Section 3). An exception might be in ocean regions where DIC-rich waters upwell to the surface. In deeper-dwelling or highlatitude species, the effect of carbonate system changes may be larger relative to temperature effects on $\mathrm{Mg} / \mathrm{Ca}$ than in the species discussed here, particularly if the habitat conditions fall at the lower end of the exponential $\mathrm{Mg} / \mathrm{Ca}$-temperature calibrations and $\left[\mathrm{CO}_{3}{ }^{2-}\right]$, DIC, or $\mathrm{pH}$ variations are large. Ultimately, the observation that no single carbonate system parameter appears to stand as a dominant control on $\mathrm{Mg} / \mathrm{Ca}$ in culture experiments leads us to recommend that carbonate system corrections not be applied to planktonic $\mathrm{Mg} / \mathrm{Ca}$ records until the specific control(s) have been identified through additional culture experiments and/or field studies. 
841

842

843

844

845

846

847

848

849

850

851

852

853

854

855

856

857

858

859

860

861

862

863

864

865

866

867

868

869

$\mathrm{U} / \mathrm{Ca}$ in $O$. universa from our carbonate system experiments agrees well with the results of Russell et al. (2004), and yields a combined U/Ca sensitivity of $-28 \pm 10 \%$ per 100 $\mu \mathrm{mol} / \mathrm{kg} \mathrm{CO}{ }_{3}^{2-}\left(\mathrm{R}^{2}=0.9\right.$, Fig. 5). We further observe a decrease in $\mathrm{U} / \mathrm{Ca}$ with temperature in O. universa of $0.51 \pm 0.32 \mathrm{nmol} / \mathrm{mol} \mathrm{per}{ }^{\circ} \mathrm{C}\left(\mathrm{R}^{2}=0.9\right.$, Fig. 5), whereas no significant temperature effect was observed by Russell et al. (2004). A U/Ca temperature decrease is predicted from thermodynamics, assuming incorporation proceeds according to the exchange reaction $\mathrm{UO}_{2}{ }^{2+}+\mathrm{CaCO}_{3}=\mathrm{Ca}^{2+}+\mathrm{UO}_{2} \mathrm{CO}_{3}$ (Russell et al., 2004). However, $\mathrm{K}_{\mathrm{eq}}$ calculated in this way is 1,000 times greater than observed $\mathrm{D}_{U}$ in foraminifera, and the theoretical rate of decrease per ${ }^{\circ} \mathrm{C}$ is also orders of magnitude higher than observed (Fig. S1). Possible reasons for the difference between this prediction and our observations are discussed in section 4.8.

Our results confirm a relationship between $\mathrm{U} / \mathrm{Ca}$ and carbonate ion. The disagreement that exists between culture experiments and core-top calibrations regarding the sensitivity of $\mathrm{U} / \mathrm{Ca}$ to temperature requires further investigation.

\section{$4.5 \mathrm{Li} / \mathrm{Ca}$}

$\mathrm{Li} / \mathrm{Ca}$ offsets between species observed in the present study indicate at least some level of biological control on the uptake of $\mathrm{Li}$ from seawater $(\mathrm{Li} / \mathrm{Ca}$ in G. ruber $>$ G. sacculifer $>$ O. universa) (Fig. 6), consistent with previous work that showed species-specific Li isotope and $\mathrm{Li} / \mathrm{Ca}$ offsets from seawater in foraminifers from core-tops (Hathorne and James, 2006). In addition, the average partitioning of Li into foraminiferal calcite in this study, $\mathrm{D}_{\mathrm{Li}}=0.006$, is higher than inorganic calcite $\mathrm{D}$ values, which range between $\sim 0.001$ to 0.002 (Okumura and Kitano, 1986; Marriott et al., 2004).

No significant change in $\mathrm{Li} / \mathrm{Ca}$ was observed in $G$. ruber or $G$. sacculifer across a temperature range from 24 to $29^{\circ} \mathrm{C}$, nor in $O$. universa from 18 to $27^{\circ} \mathrm{C}$ (Fig. 6). This is consistent with core-top studies that have found no relationship between temperature and foraminiferal Li/Ca (Delaney and Bé, 1985; Hall and Chan, 2004), but conflicts with benthic foraminifera data that show $\mathrm{Li} / \mathrm{Ca}$ decreasing with temperature (Marriott et al., 2004) and with a theoretical prediction that $\mathrm{Li} / \mathrm{Ca}$ should increase with temperature (Hall and Chan, 2004). One high $\mathrm{Li} / \mathrm{Ca}$ value stands out in our results - the low-temperature $G$. ruber experiment $\left(24^{\circ} \mathrm{C}\right)$. It is not clear why this value was high; there were no indications of contamination. There is not sufficient evidence to interpret this value in terms of a temperature effect, but this observation warrants further investigation through experiments and field studies.

In inorganic calcites, $\mathrm{Li} / \mathrm{Ca}$ increases four-fold between salinities of 10 and 50 (Marriott et al., 2004), such that a $\sim 30 \%$ increase in foraminiferal $\mathrm{Li} / \mathrm{Ca}$ might be anticipated between $S=30$ and 40 , which is $\sim 5 x$ greater than analytical uncertainty. However, salinity shows no significant influence on the $\mathrm{Li} / \mathrm{Ca}$ composition of cultured foraminifers across this range. 
870 Hall and Chan (2004) proposed that a $\left[\mathrm{CO}_{3}{ }^{2-}\right]$-driven calcification rate effect might 871 explain observations of elevated $\mathrm{Li} / \mathrm{Ca}$ in planktic foraminifera during glacial periods, but 872 in our culture experiments, $\mathrm{Li} / \mathrm{Ca}$ does not change significantly across a range of $\sim 70$ to $873600 \mu \mathrm{mol} / \mathrm{kg} \mathrm{CO}_{3}{ }^{2-}$. Moreover we have cultured the same foraminifer species as studied 874 by Hall and Chan (2004) in core-top sediments, and our $\left[\mathrm{CO}_{3}{ }^{2-}\right]$ experiments span over $875400 \mu \mathrm{mol} / \mathrm{kg}$. This is a wider range wider than any glacial-interglacial $\left[\mathrm{CO}_{3}{ }^{2-}\right]$ change 876 reconstructed to date. No significant $\mathrm{Li} / \mathrm{Ca}$ response to DIC was observed in our 877 experiments, either (Table 1). Nonetheless elevated $\mathrm{Li} / \mathrm{Ca}$ in glacial samples has been 878 documented in several species, and at other sites as well (e.g., Burton and Vance, 2000; $879 \mathrm{Ni}, 2010)$, so this is a robust observation. The lack of a carbonate ion response in our 880 experimental data highlights the need to identify the cause for elevated glacial $\mathrm{Li} / \mathrm{Ca}$ 881 records.

882

883

884

885 Partitioning of $\mathrm{Na}$ into foraminiferal calcite $\left(\mathrm{D}_{\mathrm{Na}}=0.0001\right.$, average of ambient $G$. ruber 886 and $G$. sacculifer samples) is lower than partitioning measured for inorganic calcite $\left(\mathrm{D}_{\mathrm{Na}}\right.$ 887

888 $=0.0003$ to 0.0008 , Busenberg and Plummer, 1985; White, 1978), suggesting a biological control and/or differing calcification rates between these foraminiferal and inorganic calcites. Although there is robust evidence for direct substitution of divalent cations into the $\mathrm{Ca}^{2+}$ site in calcite, the location and mechanism of univalent $(+1)$ cation

890

891

892

893 incorporation is much less clear. Similar to $\mathrm{Li}^{+}$, available inorganic data suggest $\mathrm{Na}^{+}$may be incorporated primarily at interstitial sites in the lattice (Ishikawa and Ichikuni, 1984), and observed increases in $\mathrm{Na} / \mathrm{Ca}$ with calcite growth rate may stem from a greater proportion of crystal defects leading to greater interstitial incorporation (Busenberg and Plummer, 1985). It is possible that this kind of mechanism influences $\mathrm{Na}$ incorporation in foraminiferal calcite as well, though there is no clear relationship between $\mathrm{D}_{\mathrm{Na}}$ and net calcification rate in G. ruber or G. sacculifer (Fig. 11). There does appear to be a pattern of impurity partitioning among species. For example, G. ruber consistently has the highest concentrations of $\mathrm{B}, \mathrm{Li}$, and $\mathrm{Na}$ (all non-Ca substituting elements) of all species cultured. It would be interesting to assess whether the nature of $G$. ruber calcite is more 901

902 903 conducive to impurity inclusion due to a greater occurrence of lattice imperfections or some other difference in calcite structure.

In our culture experiments, $\mathrm{Na} / \mathrm{Ca}$ of $\mathrm{G}$. ruber increases by $\sim 1 \%$ per salinity unit $(\mathrm{R}=$ $0.99, \mathrm{p}=0.01)$, but the $G$. sacculifer data are scattered $(\mathrm{R}=0.14, \mathrm{p}=0.86)$ (Fig. 7). The slope of the G. ruber $\mathrm{Na} / \mathrm{Ca}$-salinity linear regression $(0.074 \mathrm{mmol} / \mathrm{mol}$ per salinity unit) is less than half the value determined for the benthic foraminifer Ammonia tepida $(0.22$ $\mathrm{mmol} / \mathrm{mol}$ per salinity unit; Wit et al., 2013). Considering the current paucity of calibration points ( $\mathrm{n}=3$ for $G$. ruber, $\mathrm{n}=4$ for $G$. sacculifer), our calibrations should be treated with caution. According to the G. ruber calibration, an increase of 1 salinity unit should result in a $\mathrm{Na} / \mathrm{Ca}$ increase of $\sim 0.1 \mathrm{mmol} / \mathrm{mol}$. This increase, roughly the mean change predicted for the last glacial maximum, is within the estimated analytical uncertainty for $\mathrm{Na} / \mathrm{Ca}(1.7 \%$ of $6 \mathrm{mmol} / \mathrm{mol}$ equals $0.1 \mathrm{mmol} / \mathrm{mol} \mathrm{Na} / \mathrm{Ca})$. In addition, the $\mathrm{Na} / \mathrm{Ca}$ relationships with $\mathrm{S}, \mathrm{T}$, and $\mathrm{pH}$ observed in culture all predict a $\mathrm{Na}$ enrichment

915 during glacial periods; these effects will be difficult to disentangle. 


\subsection{The influence of calcification rate}

Variation in calcification rate has been called upon previously to explain trace element behavior in some biogenic calcites (e.g., Elderfield et al., 1996; Ni et al., 2007). Simple kinetic models have also been used recently to describe observed variation in $\mathrm{Sr} / \mathrm{Ca}$ and $\mathrm{Mn} / \mathrm{Ca}$ partitioning in inorganic calcite as a function of calcification rate (DePaolo, 2011; Watson, 2004). In these models, kinetic fractionation operates by "growth entrapment" of impurity ions (such as Sr). The effectiveness of this entrapment varies with crystal growth rate. Different mechanisms have been proposed, including variable rates of ion hydration and dehydration at the calcite surface (DePaolo, 2011) and competition between mineral precipitation and ion diffusion within the crystal lattice (Watson, 2004). The results of inorganic precipitation experiments appear consistent with predictions based on these growth entrapment models - with increasing precipitation rate, the incorporation of $\mathrm{Sr}^{2+}, \mathrm{Ba}^{2+}$, and $\mathrm{Na}^{+}$(larger than $\mathrm{Ca}^{2+}$ ) increases, and the incorporation of $\mathrm{Cd}^{2+}$ and $\mathrm{Mn}^{2+}$ (smaller than $\mathrm{Ca}^{2+}$ ) decreases (Fig. 13).

In principle, we should be able to evaluate the hypothesis of a rate effect in foraminiferal calcite using our trace element results alone. Given some variation in the rate of calcification, the growth-entrapment model predicts: 1) positive correlations between $\mathrm{Cd} / \mathrm{Ca}$ and $\mathrm{Mn} / \mathrm{Ca}$ (small cations) as well as between $\mathrm{Sr} / \mathrm{Ca}$ and $\mathrm{Ba} / \mathrm{Ca}$ (large cations) and 2) inverse correlations between the small and large cations (i.e., $\mathrm{Sr} / \mathrm{Ca}$ and $\mathrm{Mn} / \mathrm{Ca}$ should be inversely correlated). In addition, recent inorganic experiments suggest that $\mathrm{B} / \mathrm{Ca}$ increases with growth rate (Uchikawa et al., 2015), so if this kinetic effect applies to foraminifera, we should also see positive correlations between the large cations and $\mathrm{B} / \mathrm{Ca}$. If $\mathrm{U}$ is adsorbed at the calcite surface as $\mathrm{UO}_{2}{ }^{2+}$, it might be expected to behave like a large cation as well, i.e., its incorporation increasing with growth rate.

Our trace element results provide mixed support for these predictions (Table S2). The most consistent and significant relationships are: 1) the inverse correlation between $\mathrm{U} / \mathrm{Ca}$ and $\mathrm{B} / \mathrm{Ca}$ and 2) the positive correlation between $\mathrm{U} / \mathrm{Ca}$ and $\mathrm{Mn} / \mathrm{Ca}$. These correlations are observed in all $O$. universa experiments (temperature, salinity, and $\mathrm{pH}$ ), and are characterized by $\mathrm{R}$ values $>0.9$ and $\mathrm{p}$ values $<0.05$. Both of these prevalent correlations (U/Ca-B/Ca and $\mathrm{U} / \mathrm{Ca}-\mathrm{Mn} / \mathrm{Ca}$ ) are opposite in sign to what is predicted based on growth entrapment. In $O$. universa (the only species for which $\mathrm{Mn}, \mathrm{Cd}$, and $\mathrm{U}$ were measured), $\mathrm{Sr} / \mathrm{Ca}$ is inversely correlated with $\mathrm{Cd} / \mathrm{Ca}$ and $\mathrm{Mn} / \mathrm{Ca}$ in some experiments (consistent with growth entrapment), but not others. For example, $\mathrm{Sr} / \mathrm{Ca}$ and $\mathrm{Cd} / \mathrm{Ca}$ are inversely correlated in the salinity experiment $(\mathrm{R}=-0.70, \mathrm{p}=0.08)$, as predicted, but the correlation is not significant in the $\mathrm{pH}$ experiment $(\mathrm{R}=-0.56, \mathrm{p}=0.33) . \mathrm{Mn} / \mathrm{Ca}$ and $\mathrm{Cd} / \mathrm{Ca}$ are inversely correlated in temperature and salinity experiments $(\mathrm{R}=-0.93, \mathrm{p}=$ 0.02 and $\mathrm{R}=-0.22, \mathrm{p}=0.64$ ), contrary to expectations. $\mathrm{Ba} / \mathrm{Ca}$ does not exhibit significant relationships with $\mathrm{Sr} / \mathrm{Ca}, \mathrm{Cd} / \mathrm{Ca}$ or $\mathrm{Mn} / \mathrm{Ca}$. This is not unexpected, considering that $\mathrm{Ba} / \mathrm{Ca}$ is roughly constant across all temperature, salinity, and $\mathrm{pH}$ experiments (Hönisch et al., 2011). If symbionts preferentially remove $\mathrm{Cd}$ and/or $\mathrm{Mn}$ from the microenvironment, as suggested in the discussion above, it is possible that the expected kinetic 961 effects are not observed because they are overprinted by symbiont activity. It is not clear 
962 why $\mathrm{Sr} / \mathrm{Ca}$ and $\mathrm{Ba} / \mathrm{Ca}$, which have similar properties, behave differently. In summary, the 963 suite of trace element data does not consistently follow predictions based on growth 964 entrapment models, indicating that calcification rates (at least according to these models' predictions) do not dominate trace element incorporation in foraminifera. However, these results do not exclude a potential role for a minor (or even major) calcification rate influence for all species or under all circumstances.

Net calcification rates estimated from our culture experiments provide additional insight into the question of growth rate control on trace element incorporation. It is important to keep in mind that because we calculated calcification rates based on final postgametogenic shell weights and total growth periods, our calcification rate data represent average rates. A value of $5 \mu \mathrm{g} /$ day could be produced by slow, continuous addition of calcite at a constant rate of $5 \mu \mathrm{g} / \mathrm{day}$, or it could be produced by short periods of very rapid calcite growth $(>>5 \mu \mathrm{g}$ /day) separated by periods of very slow growth $(<<5$ $\mu \mathrm{g} /$ day) or by periods of no growth at all. There is some geochemical evidence for variation in calcification rate during the life span of $O$. universa, with faster growth during the day, perhaps peaking a few hours after first light, and slower growth at night (Spero and Parker, 1985; Spero; 1988; Lea et al., 1995; Eggins et al., 2004; Spero et al., 2015). Therefore values discussed below do not necessarily represent instantaneous calcification rates, but they do provide useful estimates of net average calcification rates for comparison with the bulk geochemical data. Our average O. universa calcification rates $(6 \pm 1 \mu \mathrm{g} /$ day $)$ overlap with a previous estimate of $\sim 7 \mu \mathrm{g} /$ day based on uptake of the radionuclide ${ }^{45} \mathrm{Ca}^{2+}$ in high-light experiments (Lea et al., 1995).

The most striking features of the calcification rate dataset are the offsets between species (Fig. 8). Net calcification rates are highest in O. universa and lowest in G. bulloides. The observation of consistently higher rates in symbiont-bearing species compared to the symbiont-barren species ( $G$. bulloides) is consistent with the idea that photosynthetic symbiont activity enhances calcification rates (Bé et al., 1992; Lea et al., 1995; Caron et al., 1982). Calcification rate differences among the three symbiont-bearing species might be related to differences in the number and/or photosynthetic activity of symbionts typically associated with foraminifers of each species type. This could be tested in future culture studies by counting the number of symbionts per host and/or quantifying photosynthesis rates (e.g., Spero and Parker, 1985).

Calcification rates do not respond uniformly to changes in experimental conditions (Figs. 8 and 9). The only significant correlations are G. sacculifer calcification rate with salinity $(\mathrm{p}=0.02)$ and $G$. sacculifer calcification rate with $\left[\mathrm{CO}_{3}{ }^{2-}\right]$ in both the $\mathrm{pH}$ and DIC experiments $(\mathrm{p}=0.004$ and 0.003 , respectively). Calcification rate in O. universa exhibits a weak correlation with temperature $(\mathrm{p}=0.08)$. The lack of a consistent response to external factors such as temperature, salinity, $\mathrm{pH}$, and $\left[\mathrm{CO}_{3}{ }^{2-}\right]$ in all (or even more than one) species suggests that foraminifera are not strongly affected by these external factors. In contrast, in inorganic calcite precipitation experiments (Uchikawa et al., 2015), calcite calcification rates increase by an order of magnitude over an experimental $\left[\mathrm{CO}_{3}{ }^{2-}\right]$ range similar to ours. The difference between the rapid response of inorganic calcite calcification rates and the undetectable or variable response of foraminiferal calcite 
1008

1009

1010

1011

1012

1013

1014

1015

1016

1017

1018

1019

1020

1021

1022

1023

1024

1025

1026

1027

1028

1029

1030

1031

1032

1033

1034

1035

1036

1037

1038

1039

1040

1041

1042

1043

1044

1045

1046

1047

1048

1049

1050

1051

1052

1053 calcification rates to $\left[\mathrm{CO}_{3}{ }^{2-}\right]$ suggests that foraminifera exert strong control over calcification rate. This makes sense given the intricate architecture of foraminiferal calcite and considering the fact that having the power to control calcification rates would aid survival (e.g., runaway calcification could lead to sinking out of the photic zone and likely mortality). A biologic control on calcification rate could also help explain the interspecies differences discussed above.

When combined with the geochemical data, the calcification rates provide new insight into some of the questions raised earlier. Based on growth entrapment model predictions, the slow-growing G. bulloides should have higher $\mathrm{Cd} / \mathrm{Ca}$ and $\mathrm{Mn} / \mathrm{Ca}$ than fast-growing O. universa, which it does (Fig. 4). Based on the same premise, O. universa should have higher $\mathrm{Sr} / \mathrm{Ca}$ and $\mathrm{Ba} / \mathrm{Ca}$ than G. bulloides, however, there is no discernible difference between these species' average values for $\mathrm{Sr} / \mathrm{Ca}$ and $\mathrm{Ba} / \mathrm{Ca}$ (Figs. 1 and 2; see also Hönisch et al., 2011). So, as in the above discussion of geochemical data, support for calcification rate effects is mixed.

When all partition coefficients ( $\mathrm{D}$ values) for all experiments are plotted against net calcification rates for each species, a few broad patterns emerge (Fig. 11). With the exception of G. bulloides, $\mathrm{D}_{\mathrm{Li}}, \mathrm{D}_{\mathrm{B}}$, and $\mathrm{D}_{\mathrm{U}}$ decrease with increasing calcification rate, while $\mathrm{D}_{\mathrm{Mg}}$ increases. $\mathrm{D}_{\mathrm{Sr}}, \mathrm{D}_{\mathrm{Ba}}, \mathrm{D}_{\mathrm{Mn}}, \mathrm{D}_{\mathrm{Cd}}$, and $\mathrm{D}_{\mathrm{Na}}$ exhibit no clear relationship to calcification rate. $\mathrm{Na} / \mathrm{Ca}$ has been observed to increase with calcification rate in inorganic experiments (Mucci, 1988), yet there is no consistent or significant relationship between net calcification rate and $\mathrm{D}_{\mathrm{Na}}$ in G. ruber and G. sacculifer (Fig. 11), suggesting that calcification rate is not the dominant control on $\mathrm{Na}$ incorporation in planktic foraminifers under these specific experimental conditions. The $\mathrm{Mg}$ ion is similar to $\mathrm{Cd}$ and $\mathrm{Mn}$ ions (same charge, similar radius), so it might be expected to behave in a similar manner. However, the increase of $\mathrm{D}_{\mathrm{Mg}}$ with calcification rate opposes the decline predicted for $\mathrm{Cd}$ and $\mathrm{Mn}$ incorporation, and $\mathrm{D}_{\mathrm{Mn}}$ and $\mathrm{D}_{\mathrm{Cd}}$ are scattered (Fig. 11).

Boron partitioning increases exponentially with growth rate (precipitation rate) in experiments with inorganic calcite (Uchikawa et al., 2015). The fit to experimental data is optimized when boron incorporation is expressed in terms of a new formulation of the empirical partition coefficient: $\lambda_{\mathrm{BT} / \mathrm{DIC}}=[\mathrm{B} / \mathrm{Ca}] /\left[\mathrm{B}_{\mathrm{T}} / \mathrm{DIC}\right]$, where $\mathrm{B}_{\mathrm{T}}=\left[\mathrm{B}(\mathrm{OH})_{4}{ }^{-}\right]+$ $\left[\mathrm{B}(\mathrm{OH})_{3}\right]$. This formulation implies that both boric acid and borate are incorporated into calcite. Uchikawa et al. (2015) speculated that boric acid incorporation might increase with growth rate in inorganic calcite. An influence of calcification rate on B incorporation in planktic foraminifers was also suggested by Ni et al. (2007) based on an observed increase in $\mathrm{B} / \mathrm{Ca}$ with shell size in core-top samples. In our G. sacculifer culture experiments, $\mathrm{B} / \mathrm{Ca}$ increases with calcification rate in $\mathrm{pH}$ experiments, but it decreases with calcification rate in DIC experiments (Fig. 14A). When data from all species are combined, the relationship between calcification rate and boron incorporation (expressed as $D_{B}$ ) is variable (Fig. 14B). If anything, $D_{B}$ appears to decrease as calcification rate increases, as does the partition coefficient suggested by Uchikawa et al. (Fig. 14C). The contrast between trends in culture and inorganic experiments suggests that the ratedependent mechanism driving B incorporation in inorganic calcites (e.g., increasing boric acid incorporation at higher calcification rates) is not active during foraminiferal 
1054 calcification, or that it is overwhelmed by other processes. Net calcification rates for 1055 foraminifers in our experiments are $\sim 100 \mathrm{x}$ slower than the slowest rates observed by 1056 Uchikawa et al. (2015), so it may be that any rate influence on B incorporation is greatly diminished or negligible at very slow growth rates, as suggested by those authors. Thus although our results do not rule out a role for calcification rates, the available data do not support a detectable influence of calcification rate on $\mathrm{B} / \mathrm{Ca}$ in planktonic foraminifera.

\subsection{Theoretical predictions, inorganic calcite, and foraminiferal calcite}

We calculated equilibrium partition coefficients for many trace elements from the Gibbs free energies of ideal products and reactants. Implicit in these thermodynamics-based calculations are several assumptions, including: 1) the system is in equilibrium, 2) the activities of all chemical species equal 1 in both solution and solid phases, and 3) substances are pure and ideal (no interactions among impurities, etc.). None of these assumptions hold in the formation of foraminiferal calcite, because net growth requires some level of disequilibrium, activities of most ions in seawater are not equal to 1 , and solutions and solids are a mixture of various components, including some organic matter. Despite the fact that these theoretical predictions are not likely to predict trace element behavior in foraminiferal calcite, considering the size and direction of different offsets between empirical distribution coefficients and their theoretical counterparts may still provide insight into trace metal incorporation.

By comparing experimental distribution coefficients (i.e., D values) with theoretical predictions ( $\mathrm{K}_{\mathrm{eq}}$ values), Rimstidt et al. (1998) found evidence for a kinetic influence on the incorporation of cations in inorganic calcite, including $\mathrm{Ba}^{2+}, \mathrm{Cd}^{2+}, \mathrm{Cu}^{2+}, \mathrm{Fe}^{2+}, \mathrm{Mg}^{2+}$, $\mathrm{Mn}^{2+}, \mathrm{Sr}^{2+}$, and $\mathrm{UO}_{2}{ }^{2+}$. Those authors also observed a consistently larger offset between theoretical and empirical partition coefficients for cations larger than $\mathrm{Ca}^{2+}$ (e.g., $\mathrm{Sr}^{2+}$, $\mathrm{Ra}^{2+}, \mathrm{Ba}^{2+}$ ) than for ions smaller than $\mathrm{Ca}^{2+}$. Rimstidt et al. (1998) suggested that the larger offset might be due to the fact that large ions do not fit as easily into the calcite lattice as smaller ions, and that partitioning is optimized as ions approach the ionic radius of $\mathrm{Ca}^{2+}$. The $\mathrm{D}$ values for inorganic calcite and foraminiferal calcite (Fig. 13) appear largely consistent with these ideas. Foraminiferal D values increase with increasing ionic radius from $\mathrm{Mg}$ to $\mathrm{Li}$ to $\mathrm{Mn}$ (Cd is an exception, discussed below), and the larger cations $\mathrm{Sr}^{2+}$ and $\mathrm{Ba}^{2+}$ are characterized by smaller $\mathrm{D}$ than $\mathrm{Mn}$ and $\mathrm{Cd}$.

For some elements like $\mathrm{Ba}, \mathrm{Sr}, \mathrm{Na}$, and $\mathrm{Mn}$, the partitioning into foraminifera and inorganic calcites is similar, indicated by roughly equivalent $\mathrm{D}$ values (Fig. 13). This suggests that a simple combination of thermodynamic and kinetic factors may reasonably predict element behavior, as in Rimstidt et al. (1998). In contrast, some elements are not easily explained by thermodynamics and kinetics alone. Some offsets between inorganic and foraminiferal D values suggest biological control on the composition of calcifying fluids and/or biogenic calcite, or perhaps activity coefficients that significantly differ from 1. For example, the partition coefficient for $\mathrm{Cd} / \mathrm{Ca}$ in $O$. universa $\left(\mathrm{D}_{\mathrm{Cd}}{ }^{\text {foram }}\right)$ is orders of magnitude smaller than both the inorganic and theoretical partition coefficients. This could be caused by selective uptake of Cd by symbionts, as proposed by Mashiotta et al. (1997). Partitioning of $\mathrm{Mg} / \mathrm{Ca}$ is also lower in foraminifera than in inorganic calcites (Lea 
1100

1101

1102

1103

1104

1105

1106

1107

1108

1109

1110

1111

1112

1113

1114

1115

1116

1117

1118

1119

1120

1121

1122

1123

1124

1125

1126

1127

1128

1129

1130

1131

1132

1133

1134

1135

1136

1137

1138

1139

1140

1141

1142

1143

1144

1145

et al., 1999; Russell et al., 2004), which might be due to selective ion pumping exercised to make calcite precipitation more energetically favorable (Zeebe and Sanyal, 2002).

For the singly charged cations $\mathrm{Li}^{+}$and $\mathrm{Na}^{+}$, theoretical predictions are several orders of magnitude lower than observations (Fig. 13). This is likely due to multiple factors, one of which is that the calculation was performed assuming the substitution reaction $2 \mathrm{Li}^{2+}+$ $\mathrm{CaCO}_{3}=\mathrm{Li}_{2} \mathrm{CO}_{3}+\mathrm{Ca}^{2+}$ (same for $\mathrm{Na}^{+}$). If these ions are incorporated in interstitial positions, as discussed above, and/or they are not competing with $\mathrm{Ca}^{2+}$ for lattice sites (Langer et al., 2015), then this equation would not be applicable to inorganic or foraminiferal calcite samples.

\subsection{Calcification mechanisms}

To understand foraminiferal calcite composition, we must not only consider fundamental inorganic trace element partitioning and kinetic effects, but also biological modification of calcifying fluid composition. Living organisms employ many strategies to induce and control calcite growth, and in foraminifera these strategies appear to focus on the isolation and modification of seawater (e.g., Bé and Hemleben, 1970; Bentov et al., 2009; Erez, 2003; Nehrke et al., 2013). The manipulation of barriers to nucleation and growth through addition or removal of key compounds seems to play an important role as well. Many mechanisms have been proposed, including seawater vacuolization, pumping of $\mathrm{Ca}^{2+}, \mathrm{Mg}^{2+}, \mathrm{H}^{+}$, or $\mathrm{HCO}_{3}^{-}$, carbon concentration via diffusion of $\mathrm{CO}_{2}$ across a concentration gradient, formation and delivery of amorphous calcium carbonate to sites of calcification, and others, though direct observations of most internal processes are limited (de Nooijer et al., 2014; Elderfield et al., 1996; Erez, 2003; Zeebe and Sanyal, 2002).

One of the models first proposed to explain trace element incorporation in foraminifera is based on the assumption that seawater is vacuolized, and then only a fraction $(f)$ of this internal pool of ions is utilized for calcification (Elderfield et al., 1996). To assess whether the present culture data are consistent with such a model, we calculated empirical partition coefficients using inorganic partition coefficients $(\alpha)$ via a Rayleigh distillation equation $\left(\mathrm{D}_{\operatorname{Tr}}=\left(1-f^{\mathrm{a}}\right) /(1-f)\right)$. If the model's assumptions are correct, each observed foraminiferal partition coefficient $\left(\mathrm{D}_{\text {foram }}\right)$ should yield a utilization fraction $f$ that is consistent with estimates from other trace elements. However, this is not the case according to the Rayleigh calculations, $\mathrm{Mg}, \mathrm{Zn}, \mathrm{Na}$, and $\mathrm{U}$ results imply a $>99 \%$ utilization of the reservoir while Ba and Li imply $<1 \%$ utilization. Both can not be correct. This outcome does not preclude the possibility that variable fractions of an internal seawater reservoir are used during calcification, but it does indicate that other processes involving selective transport and/or selective incorporation or discrimination of different elements are at work.

\subsection{Searching for a useful conceptual framework}

Although many questions remain unanswered, we know all calcification mechanisms are unified by a common goal: to combine dissolved components into a solid shell. To 
1146

1147

1148

1149

1150

1151

1152

1153

1154

1155

1156

1157

1158

1159

1160

1161

1162

1163

1164

1165

1166

1167

1168

1169

1170

1171

1172

1173

1174

1175

1176

1177

1178

1179

1180

1181

1182

1183

1184

1185

1186

1187

1188

1189

1190

1191

achieve this, foraminifera must manipulate the "energy landscape" between solution and solid. This concept is described by De Yoreo and Vekilov (2003): “... crystallization is, first and foremost, a phase transition through which matter is transformed from a state of high free energy in a solvated state to one of low free energy in the crystal lattice. All aspects of a crystal, including its phase, habit, and growth rate, are determined by the shape of the landscape." To fully understand trace element partitioning between seawater and foraminiferal calcite, we will need to consider the underlying inorganic controls and biological calcification mechanisms in a unified conceptual framework. In the current study, we attempt to lay some groundwork for such a holistic view. We argue that measurements of physiological processes such as foraminiferal calcification rates, the role of pumps and channels, and symbiont activity are needed to enhance our understanding of trace element partitioning. In addition, more experiments that target the effects of changing the major element composition of seawater are needed. For geological applications, it will also be important to consider the long-term or evolutionary response of foraminifera to environmental changes, which may differ from the short-term (single lifespan) responses we have described here.

\section{Conclusions}

Culture experiments with O. universa, G. ruber (pink), G. sacculifer and G. bulloides were conducted to quantify relationships between the trace element composition of planktic foraminiferal calcite and environmental growth conditions.

1. In G. sacculifer, the response of $\mathrm{Sr} / \mathrm{Ca}$ to rising $\left[\mathrm{CO}_{3}{ }^{2-}\right]$ is $\sim 12 \mathrm{x}$ greater in DIC experiments (constant $\mathrm{pH}$ ) than in $\mathrm{pH}$ experiments (constant DIC). Predicted $\mathrm{Sr} / \mathrm{Ca}$ changes across Pleistocene glacial cycles are smaller than analytical uncertainty; however, the $\mathrm{Sr} / \mathrm{Ca}$-DIC relationship may be useful for evaluating more dramatic carbon cycle changes earlier in the Cenozoic.

2. In $G$. ruber, $\mathrm{Na} / \mathrm{Ca}$ increases $\sim 1 \%$ per salinity unit, but no significant relationship is observed in G. sacculifer. According to the G. ruber calibration, an increase of 1 salinity unit should result in a $\mathrm{Na} / \mathrm{Ca}$ increase of $\sim 0.1 \mathrm{mmol} / \mathrm{mol}$. This salinity increase, roughly the mean change predicted for the last glacial maximum, is within the estimated analytical uncertainty for $\mathrm{Na} / \mathrm{Ca}(1.7 \%$ of $6 \mathrm{mmol} / \mathrm{mol}$ equals $0.1 \mathrm{mmol} / \mathrm{mol} \mathrm{Na} / \mathrm{Ca})$. In addition, the $\mathrm{Na} / \mathrm{Ca}$ relationships with $\mathrm{S}, \mathrm{T}$, and $\mathrm{pH}$ observed in culture all predict a $\mathrm{Na}$ enrichment during glacial periods. Therefore, independent proxies are needed to disentangle these separate influences on $\mathrm{Na} / \mathrm{Ca}$.

3. Incorporation of some of the smaller cations $(\mathrm{Cd}, \mathrm{Mn})$ decreases in $O$. universa as $\left[\mathrm{CO}_{3}{ }^{2-}\right]$ increases. $\mathrm{Mg} / \mathrm{Ca}$ decreases with $\left[\mathrm{CO}_{3}{ }^{2-}\right]$ in $\mathrm{pH}$ experiments, consistent with previous work (Evans et al., 2016; Lea et al., 1999; Russell et al., 2004), but $\mathrm{Mg} / \mathrm{Ca}$ increases slightly with $\left[\mathrm{CO}_{3}{ }^{2-}\right]$ in DIC experiments. This suggests that the response of $\mathrm{Mg} / \mathrm{Ca}$ to the carbonate system does not solely depend upon $\left[\mathrm{CO}_{3}{ }^{2-}\right]$. Any carbonate system effects on $\mathrm{Mg} / \mathrm{Ca}$ are expected to be within analytical error for most late Pleistocene records. In light of the small contribution and uncertain nature of carbonate system influences on paleo $\mathrm{Mg} / \mathrm{Ca}$ records, corrections are not recommended. 
4. Net calcification rates vary by species $(O$. universa $>$ G. sacculifer $>G$. ruber $>G$. bulloides), ranging from $0.3 \pm 0.1$ to $6 \pm 1 \mu \mathrm{g} /$ day. Calcification rates do not respond consistently to any experimental parameter (temperature, salinity, $\mathrm{pH}, \mathrm{DIC},\left[\mathrm{CO}_{3}{ }^{2-}\right]$ ). Calcification rate behavior in the species studied here contrasts with results of inorganic calcite precipitation experiments, indicating that foraminifera exert strong control over the rate of shell growth. On average, cultured foraminifera grow more slowly $(\sim 100 \mathrm{x})$ than inorganic calcite in recent experiments.

5. In general, thermodynamic calculations fail to predict observed trace element behavior in cultured planktic foraminifera. Instead, our results suggest that a combination of thermodynamic and kinetic controls largely explain the behavior of some trace metals $(\mathrm{Mn}, \mathrm{Cd}, \mathrm{Sr}, \mathrm{Ba}$ ) and biological controls likely play a role in others $(\mathrm{Mg}, \mathrm{Cd})$. Our results highlight the need to further examine both kinetic and biologic controls on trace element proxies. In addition, it is essential to test these culture calibrations in the open ocean (e.g., through core-top and sediment trap studies) to confirm that the trace element behavior observed in the laboratory holds in the natural environment.

\section{Acknowledgments}

We are grateful to the staff at the USC Wrigley Institute for their support during our field work on Catalina Island and at the University of Puerto Rico Isla Magueyes Laboratories, especially Milton Carlo and Godoberto Lopez. These experiments were made possible by our scuba and laboratory teams: Steve Doo, Kelly Strzepek, Lael Vetter, Juan Pablo D'Olivo Cordero, Rebecca Norman, Kate Holland, Ann Russell, Alex Gagnon, and Jordan Snyder. Many thanks to Tali Babila, Katherine Esswein, Stella Woodard, Jason Day, Mervyn Greaves, and Harry Elderfield for sharing their time and analytical expertise. KA would also like to thank Taro Takahashi and Bob Anderson at LamontDoherty Earth Observatory and Tali Babila, now at UC Santa Cruz, for valuable discussions. We are grateful for the thoughtful comments from David Lea and two anonymous reviewers that greatly improved this manuscript. This research was funded by a Columbia Climate Center Grant (KA and BH), NSF grants OCE 07-51764 and OCE 12-32987 (BH), ARC grants DP0880010 and DP110103158 (SME).

FIGURES 1-14 (and S1, S2) in separate file.

TABLES in separate Excel file.

\section{FIG. CAPTIONS:}

1237

Fig. 1. Summary of trace metal data from this study (circles) with results from previous studies.

Fig. 2. In four species, $\mathrm{Sr} / \mathrm{Ca}$ responses to temperature and salinity are not significant ( $\mathrm{p}$ $>0.05)$. When $\left[\mathrm{CO}_{3}{ }^{2-}\right]$ is increased by raising DIC and holding $\mathrm{pH}$ constant, the response of $\mathrm{Sr} / \mathrm{Ca}$ to $\left[\mathrm{CO}_{3}{ }^{2-}\right]$ is $\sim 12 \mathrm{x}$ greater than when $\left[\mathrm{CO}_{3}{ }^{2-}\right]$ is raised by increasing $\mathrm{pH}$. This 
1238

1239

1240

1241

1242

1243

1244

1245

1246

1247

1248

1249

1250

1251

1252

1253

1254

1255

1256

1257

1258

1259

1260

1261

1262

1263

1264

1265

1266

1267

1268

1269

1270

1271

1272

1273

1274

1275

1276

1277

1278

1279

1280

1281

1282

1283

suggests that $\mathrm{Sr} / \mathrm{Ca}$ is not merely a simple function of $\left[\mathrm{CO}_{3}{ }^{2-}\right]$. $\mathrm{Sr} / \mathrm{Ca}$ values are expected to differ between $O$. universa experiments due to differences in $\mathrm{Sr} / \mathrm{Ca}$ of seawater between "modern" and "Paleocene" experimental seawater (black circles and diamonds, respectively).

Fig. 3. $\mathrm{Sr} / \mathrm{Ca}$ of planktic foraminiferal calcite increases linearly with seawater $\mathrm{Sr} / \mathrm{Ca}$. Black circles represent data from culture experiments (this study, ambient DIC experiments, average $\mathrm{D}_{\mathrm{Sr}}=0.16$ ); colored lines were drawn based on average $\mathrm{D}_{\mathrm{Sr}}$ values determined in previous studies.

Fig. 4. $\mathrm{Mg} / \mathrm{Ca}, \mathrm{Mn} / \mathrm{Ca}$, and $\mathrm{Cd} / \mathrm{Ca}$ generally decrease with increasing seawater $\left[\mathrm{CO}_{3}{ }^{2-}\right]$, with the effect decreasing or disappearing above ambient $\mathrm{pH} . \mathrm{Mg} / \mathrm{Ca}$ of $\mathrm{G}$. sacculifer does not appear to respond to $\left[\mathrm{CO}_{3}{ }^{2-}\right]$. Trace element incorporation varies among species, with $O$. universa having the highest $\mathrm{Mg} / \mathrm{Ca}$ and G. bulloides having the highest $\mathrm{Mn} / \mathrm{Ca}$ and $\mathrm{Cd} / \mathrm{Ca}$.

Fig. 5. In this study, O. universa $\mathrm{U} / \mathrm{Ca}$ decreases $0.51 \pm 0.32 \mathrm{nmol} / \mathrm{mol}$ per ${ }^{\circ} \mathrm{C}\left(\mathrm{R}^{2}=0.9\right)$, unlike previous work in which a temperature influence was not observed (Russell et al., 2004). U/Ca may also decrease with salinity, though this relationship is not as strong $\left(0.51 \pm 0.54 \mathrm{nmol} / \mathrm{mol}\right.$ per salinity unit, $\left.\mathrm{R}^{2}=0.5\right)$. Our carbonate ion relationship agrees well with trends observed for O. universa and G. bulloides in Russell et al. (2004).

Fig. 6. $\mathrm{Li} / \mathrm{Ca}$ does not exhibit consistent or significant relationships with growth temperature, salinity, or carbonate ion across the experimental ranges in this study. Consistent $\mathrm{Li} / \mathrm{Ca}$ offsets between species imply some form of biological control or influence on Li incorporation. Error bars represent $\pm 5.8 \%$ RSD.

Fig. 7. In G. ruber, $\mathrm{Na} / \mathrm{Ca}$ increases with salinity $(\mathrm{R}=0.99, \mathrm{p}=0.01)$, however, the possible influence of other variables (temperature and carbonate ion) suggests that $\mathrm{Na} / \mathrm{Ca}$ as a salinity proxy in G. ruber requires further testing. The lowest and highest $\mathrm{CO}_{3}{ }^{2-}$ experiments correspond to $\mathrm{pH}$ values of $\sim 7.8$ and 8.7 (total scale), respectively. See Table $\mathrm{S} 1$ for full experimental details.

Fig. 8. Net average calcification rates $( \pm 1 \sigma)$ calculated from shell weights and number of growth days in culture $(\mu \mathrm{g} /$ day). Calcification rates vary among species: G. bulloides $<$ G. ruber $<$ G. sacculifer $<O$. universa (Table S1).

Fig. 9. Relationships between net calcification rates $( \pm 1 \sigma)$ and experimental parameters (temperature, salinity, $\left[\mathrm{CO}_{3}{ }^{2-}\right]$ ) are species specific. See text for full discussion.

Fig. 10. In inorganic calcites, $\mathrm{Sr} / \mathrm{Ca}$ increases with calcification rate, and calcification rate increases as the ratio of $\mathrm{CO}_{3}{ }^{2-}$ to $\mathrm{Ca}^{2+}$ in solution approaches 1 (Nehrke et al, 2007). When cultured G. sacculifer and $O$. universa data are plotted with the inorganic data, it appears that the DIC culture experiments (red circles) parallel the inorganic data, while the $\mathrm{pH}$ culture experiments follow a different trend (blue circles). Assuming that foraminifera vacuolize seawater and then raise its $\mathrm{pH}$ to 9 (total scale), $\left[\mathrm{CO}_{3}{ }^{2-}\right]$ increases 
1284 in the vacuoles (black arrows) and foraminiferal $\mathrm{D}_{\mathrm{Sr}}$ from both $\mathrm{pH}$ and DIC experiments exhibit a correlation with $\mathrm{CO}_{3}{ }^{2-} / \mathrm{Ca}^{2+}$ similar to inorganic observations.

Fig. 11. Empirical partition coefficients $\left(\mathrm{D}=[\mathrm{TE} / \mathrm{Ca}]_{\text {calcite }} /[\mathrm{TE} / \mathrm{Ca}]_{\text {seawater }}\right)$ vs. net bulloides.

Fig. 12. In G. sacculifer, $\mathrm{Mg} / \mathrm{Ca}$ increases with DIC (and also $\left[\mathrm{CO}_{2}\right],\left[\mathrm{CO}_{3}{ }^{2-}\right]$ and $\left[\mathrm{HCO}_{3}{ }^{2-}\right]$ ) in constant-pH, variable-DIC experiments. In these experiments, $\mathrm{Mg} / \mathrm{Ca}$ increased with $\left[\mathrm{CO}_{3}{ }^{2-}\right]$, in contrast to the decrease with $\left[\mathrm{CO}_{3}{ }^{2-}\right]$ observed in $\mathrm{pH}$ experiments (c.f. Fig. 3). Thus the relationship between $\mathrm{Mg} / \mathrm{Ca}$ and $\left[\mathrm{CO}_{3}{ }^{2-}\right]$ is not straightforward.

Fig. 13. Comparison of empirical partition coefficients for cultured foraminifera (this study, $\mathrm{D}_{\text {foram }}$, circles) and inorganic calcites (previous studies, $\mathrm{D}_{\text {inorg }}$, triangles). Averages are provided in Table S3. For a full list of sources for inorganic data, see Table S4. Effective ionic radii $(\AA)$ are from Shannon et al. (1969), LS = low spin radius, HS = high spin radius. Fig. after Onuma (1979) and Rimstidt (1998). Dashed-line boxes around $\mathrm{Li}^{+}$ and $\mathrm{Na}^{+}$emphasize that these monovalent ions may not compete with $\mathrm{Ca}^{2+}$ for inclusion in the lattice; see text for full discussion.

Fig. 14. (A) In $\mathrm{pH}$ and DIC experiments with G. sacculifer, $\mathrm{D}_{\mathrm{B}}$ is not controlled by net calcification rate. (B) All $\mathrm{D}_{\mathrm{B}}$ for all experiments for which net calcification rates were calculated. (C) Same data as in B, except plotted as the partition coefficient suggested by Uchikawa et al. (2015). Boron partitioning into calcite is variable and, if anything, appears to decrease with increasing calcification rate in contrast to experiments with inorganic calcite. This suggests foraminifers actively control calcification rate and/or B incorporation.

\section{$\underline{\text { References }}$}

Allen, K. A., Hönisch, B., Eggins, S. M., and Rosenthal, Y., 2012. Environmental controls on $\mathrm{B} / \mathrm{Ca}$ in calcite tests of the tropical planktic foraminifer species Globigerinoides ruber and Globigerinoides sacculifer. Earth Planet. Sci. Lett. 351, 270-280.

1324

1325

Allen, K. A., Hönisch, B., Eggins, S. M., Yu, J., Spero, H. J., and Elderfield, H., 2011. Controls on boron incorporation in cultured tests of the planktic foraminifer Orbulina universa. Earth Planet. Sci. Lett. 309, 291-301.

Allen, K.A., Hönisch, B., 2012. The planktic foraminiferal B/Ca proxy for seawater carbonate chemistry: A critical evaluation. Earth Planet. Sci. Lett. 345, 203-211. 
1326

1327

1328

1329

1330

1331

1332

1333

1334

1335

1336

1337

1338

1339

1340

1341

1342

1343

1344

1345

1346

1347

1348

1349

1350

1351

1352

1353

1354

1355

1356

1357

1358

1359

Anand, P., Elderfield, H., and Conte, M. H., 2003. Calibration of Mg/Ca thermometry in planktonic foraminifera from a sediment trap time series. Paleoceanography 18, 15.

Babila, T. L., Rosenthal, Y., \& Conte, M. H. (2014). Earth and Planetary Science Letters. Earth and Planetary Science Letters, 404(C), 67-76.

Bé, A. W. H. and Hemleben, C., 1970. Calcification in a living planktonic foraminifer, Globigerinoides sacculifer (BRADY). N. Jb. Geol. Paläont. Abh. 134, 221-234.

Bentov, S., Brownlee, C., and Erez, J., 2009. The role of seawater endocytosis in the biomineralization process in calcareous foraminifera. Proceedings of the National Academy of Sciences of the United States of America 106, 21500-21504.

Bijma, J., Faber Jr., W. W., and Hemleben, C., 1990. Temperature and salinity limits for growth and survival of some planktonic foraminifers in laboratory cultures. Journal of Foraminiferal Research 20, 95-116.

Billups, K., Rickaby, R. E. M., and Schrag, D. P., 2004. Cenozoic pelagic Sr/Ca records: Exploring a link to paleoproductivity. Paleoceanography 19.

Boyle, E. A., 1988. The role of vertical chemical fractionation in controlling late Quaternary atmospheric carbon dioxideJournal of Geophysical Research.

Burton, K. W. and Vance, D., 2000. Glacial-interglacial variations in the neodymium isotope composition of seawater in the Bay of Bengal recorded by planktonic foraminifera. Earth Planet. Sci. Lett. 176, 425-441.

Busenberg, E. and Plummer, L. N., 1985. Kinetic and thermodynamic factors controlling the distribution of SO4(2-) and $\mathrm{Na}+$ in calcites and selected aragonites. Geochim. Cosmochim. Acta 49, 713-725.

Cléroux, C., Cortijo, E., Duplessy, J.-C., \& Zahn, R. (2007). Deep-dwelling foraminifera as thermocline temperature recorders. Geochemistry Geophysics Geosystems, $8(4)$.

Davis, K. J., Dove, P. M., and De Yoreo, J. J., 2000. The role of $\mathrm{Mg}^{2+}$ as an impurity in calcite growth. Science 290, 1134-1137.

de Nooijer, L. J., Spero, H. J., Erez, J., Bijma, J., and Reichart, G. J., 2014. Biomineralization in perforate foraminifera. Earth-Science Reviews 135, 48-58.

De Yoreo, J. J. and Vekilov, P. G., 2003. Principles of crystal nucleation and growth. In: Dove, P. M. D. J. J. W. S. (Ed.), Biomineralization.

Delaney, M. L., 1989. Uptake of Cadmium into Calcite Shells by Planktonic Foraminifera Chem. Geol. 78, 159-165. 
1360 Delaney, M. L. and Bé, A. W. H. B., E.A., 1985. Li, Sr, Mg, and Na in foraminiferal calcite shells from laboratory culture, sediment traps and sediment cores. Geochim. Cosmochim. Acta.

Delaney, M. L. and Boyle, E. A., 1986. Lithium in foraminiferal shells - Implications for high-temperature hydrothermal circulation fluxes and oceanic crustal generation rates. Earth Planet. Sci. Lett. 80, 91-105.

DePaolo, D. J., 2011. Surface kinetic model for isotopic and trace element fractionation during precipitation of calcite from aqueous solutions. Geochim. Cosmochim. Acta 75, 1039-1056.

Dickson, A. G., Sabine, C. L., and Christian, J. R., 2007. Guide to best practices for ocean $\mathrm{CO} 2$ measurements. PICES Special Publication 3.

1371 Djogić, R., \& Branica, M. (1991). Dissolved uranyl complexed species in artificial seawater. Marine Chemistry, 36, 121-125.

Dromgoole, E. L. and Walter, L. M., 1990. Iron and Manganese incorporation into calcite - Effects of growth kinetics, temperature and solution chemistry. Chem. Geol. 81, 311-336.

Dueñas-Bohórquez, A., da Rocha, R. E., Kuroyanagi, A., Bijma, J., and Reichart, G. J., 2009. Effect of salinity and seawater calcite saturation state on $\mathrm{Mg}$ and $\mathrm{Sr}$ incorporation in cultured planktonic foraminifera. Mar. Micropaleontol. 73, 178189.

Eggins, S., De Deckker, P., and Marshall, J., 2003. Mg/Ca variation in planktonic foraminifera tests: implications for reconstructing palaeo-seawater temperature and habitat migration. Earth Planet. Sci. Lett. 212, 291-306.

Eggins, S. M., Sadekov, A., and De Deckker, P., 2004. Modulation and daily banding of $\mathrm{Mg} / \mathrm{Ca}$ in Orbulina universa tests by symbiont photosynthesis and respiration: a complication for seawater thermometry? Earth Planet. Sci. Lett. 225, 411-419.

Elderfield, H., Bertram, C. J., and Erez, J., 1996. A biomineralization model for the incorporation of trace elements into foraminiferal calcium carbonateEarth Planet. Sci. Lett.

Elderfield, H., Vautravers, M., and Cooper, M., 2002. The relationship between shell size and $\mathrm{Mg} / \mathrm{Ca}, \mathrm{Sr} / \mathrm{Ca}, \delta^{18} \mathrm{O}$, and $\delta^{13} \mathrm{C}$ of species of planktonic foraminifera. Geochem. Geophys. Geosyst. 3, DOI 10.1029/2001GC000194.

1394 Emiliani, 1955. Pleistocene Temperatures. The Journal of Geology 63, 538-578. 
1395 Erez, J., 2003. The source of ions for biomineralization in foraminifera and their implications for paleoceanographic proxies. Rev. Mineral. Geochem. 54, 115-149.

1397 Evans, D., Wade, B. S., Henehan, M., Erez, J., and Müller, W., 2015. Revisiting 1398

1399

1400

1401

1402

1403

1404

1405

1406

1407

1408

Gabitov, R. I. and Watson, E. B., 2006. Partitioning of strontium between calcite and fluid. Geochem. Geophys. Geosyst. 7, 12.

1410

1411

1412

1413

1414

1415

1416

1417

1418

1419

1420

1421

1422

1423

1424

1425

1426

1427

1428

1429

1430

1431 Haynes, W. M., 2014. CRC Handbook of Chemistry and Physics, $95^{\text {th }}$ Edition. 
1432

1433

1434

1435

1436

1437

1438

1439

1440

1441

1442

1443

1444

1445

1446

1447

1448

1449

1450

1451

1452

1453

1454

1455

1456

1457

1458

1459

1460

1461

1462

1463

1464

1465

1466

1467

1468
Hemming, N. G., \& Hanson, G. N. (1992). Boron isotopic composition and concentration in modern marine carbonates. Geochimica Et Cosmochimica Acta, 56(1), 537543.

Hendry, K.R., Rickaby, R.E.M., Meredith, M.P., Elderfield, H., 2009. Controls on stable isotope and trace metal uptake in Neogloboquadrina pachyderma (sinistral) from an Antarctic sea-ice environment. Earth Planet. Sci. Lett. 278, 67-77.

Henehan, M.J., Rae, J.W.B., Foster, G.L., Erez, J., Prentice, K.C., Kucera, M., Bostock, H.C., Martinez-Boti, M.A., Milton, J.A., Wilson, P.A., Marshall, B.J., Elliott, T., 2013. Calibration of the boron isotope proxy in the planktonic foraminifera Globigerinoides ruber for use in palaeo- $\mathrm{CO}_{2}$ reconstruction. Earth Planet. Sci. Lett. 364, 111-122.

Hönisch, B., Allen, K. A., Russell, A. D., Eggins, S. M., Bijma, J., Spero, H. J., et al. (2011). Planktic foraminifers as recorders of seawater $\mathrm{Ba} / \mathrm{Ca}$. Marine Micropaleontology, 79(1-2), 52-57.

Hönisch, B., Allen, K. A., Lea, D. W., Spero, H. J., Eggins, S. M., Arbuszewski, J., deMenocal, P., Rosenthal, Y., Russell, A. D., and Elderfield, H., 2013. The influence of salinity on $\mathrm{Mg} / \mathrm{Ca}$ in planktic foraminifers - Evidence from cultures, core-top sediments and complementary delta O-18. Geochim. Cosmochim. Acta 121, 196-213.

Ichikuni, M. and Kikuchi, K., 1972. Retention of boron by travertines. Chem. Geol. 9, 1321.

Ishikawa, M. and Ichikuni, M., 1984. Uptake of sodium and potassium by calcite. Chem. Geol. 42, 137-146.

Jørgensen, B. B., Erez, J., Revsbech, N. P., and Cohen, Y., 1985. Symbiotic photosynthesis in a planktonic foraminiferan, Globigerinoides sacculifer (Brady), studied with microelectrodes. Limnol. Oceanogr. 30, 1253-1267.

Keul, N., Langer, G., de Nooijer, L. J., Nehrke, G., Reichart, G. J., and Bijma, J., 2013. Incorporation of uranium in benthic foraminiferal calcite reflects seawater carbonate ion concentration. Geochem. Geophys. Geosyst. 14, 102-111.

Khider, D., Jackson, C. S., and Stott, L. D., 2014. Assessing millennial-scale variability during the Holocene: A perspective from the western tropical Pacific. Paleoceanography 29, 143-159.

K1sakürek, B., Eisenhauer, A., Böhm, F., Garbe-Schönberg, D., and Erez, J., 2008. Controls on shell $\mathrm{Mg} / \mathrm{Ca}$ and $\mathrm{Sr} / \mathrm{Ca}$ in cultured planktonic foraminiferan, Globigerinoides ruber (white). Earth Planet. Sci. Lett. 273, 260-269. 
1469

1470

1471

1472

1473

1474

1475

1476

1477

1478

1479

1480

1481

1482

1483

1484

1485

1486

1487

1488

1489

1490

1491

1492

1493

1494

1495

1496

1497

1498

1499

1500

1501

1502

1503

Klinkhammer, G. P., Mix, A. C., and Haley, B. A., 2009. Increased dissolved terrestrial input to the coastal ocean during the last deglaciation. Geochem. Geophys. Geosyst. 10.

Klinkhammer, G. P. and Palmer, M. R., 1991. Uranium in the oceans: Where it goes and why. Geochim. Cosmochim. Acta 55, 1799-1806.

Lea, D.W., Spero, H.J., 1994. Assessing the reliability of paleochemical tracers: barium uptake in the shells of planktonic foraminifera. Paleoceanography 9, 445-452.

Lea, D. W., Martin, P. A., Chan, D. A., and Spero, H. J., 1995. Calcium uptake and calcification rate in the planktonic foraminifer Orbulina universa. Journal of Foraminiferal Research 25, 14-23.

Lea, D. W., 1999. Trace elements in foraminiferal calcite. In: Sen Gupta, B. K. (Ed.), Modern Foraminifera. Kluwer Academic Publishers, Great Britain.

Lea, D. W., 2003. Elemental and Isotopic Proxes of Past Ocean Temperatures. In: Holland, H. and Turekian, K. (Ed.) Treatise on Geochemistry. Elsevier.

Lea, D. W., Martin, P. A., Chan, D. A., and Spero, H. J., 1995. Calcium uptake and calcification rate in the planktonic foraminifer Orbulina universa. Journal of Foraminiferal Research 25, 14-23.

Lea, D. W., Mashiotta, T. A., and Spero, H. J., 1999b. Controls on magnesium and strontium uptake in planktonic foraminifera determined by live culturing. Geochim. Cosmochim. Acta 63, 2369-2379.

Lea, D. W., 2004. Elemental and Isotopic Proxies of Past Ocean Temperatures.

Lorens, R. B., 1981. Sr, Cd, Mn and Co distribution coefficients as a function of calcite precipitation rate. Geochim. Cosmochim. Acta.

Lueker, T. J., Dickson, A. G., and Keeling, C. D., 2000. Ocean pCO2 calculated from dissolved inorganic carbon, alkalinity, and equations for $\mathrm{K}-1$ and $\mathrm{K}-2$ : validation based on laboratory measurements of $\mathrm{CO} 2$ in gas and seawater at equilibrium. Mar. Chem. 70, 105-119.

Marr, J. P., Carter, L., Bostock, H. C., Bolton, A., and Smith, E., 2013. Southwest Pacific Ocean response to a warming world: Using $\mathrm{Mg} / \mathrm{Ca}, \mathrm{Zn} / \mathrm{Ca}$, and $\mathrm{Mn} / \mathrm{Ca}$ in foraminifera to track surface ocean water masses during the last deglaciation. Paleoceanography 28, 347-362.

Marriott, C. S., Henderson, G. M., Crompton, R., Staubwasser, M., and Shaw, S., 2004. Effect of mineralogy, salinity, and temperature on $\mathrm{Li} / \mathrm{Ca}$ and $\mathrm{Li}$ isotope composition of calcium carbonate. Chem. Geol. 212, 5-15. 
1504 Martin, P. A., Lea, D. W., Mashiotta, T. A., Papenfuss, T., and Sarnthein, M., 1999. Variation of foraminiferal $\mathrm{Sr} / \mathrm{Ca}$ over Quaternary glacial-interglacial cycles: Evidence for changes in mean ocean $\mathrm{Sr} / \mathrm{Ca}$ ? Geochem. Geophys. Geosyst. 1, Paper No.: 1999GC000006.

Mashiotta, T. A., Lea, D. W., and Spero, H. J., 1997. Experimental determination of Cd uptake in shells of the planktonic foraminifera Orbulina universa and Globigerina bulloides: Implications for surface water paleoreconstructions. Geochim. Cosmochim. Acta 61, 4053-4065.

Morse, J. W. and Bender, M. L., 1990. Partition coefficients in calcite: Examination of factors influencing the validity of experimental results and their application to natural systems, Chem. Geol. 82, 265-277.

Mucci, A., 1988. Manganese uptake during calcite precipitation from seawater: Conditions leading to the formation of a pseudokutnahorite. Geochimica et Cosmochimica Acta, 52 (7), 1859-1868.

Nehrke, G., Keul, N., Langer, G., de Nooijer, L. J., Bijma, J., and Meibom, A., 2013. A new model for biomineralization and trace-element signatures of Foraminifera tests. Biogeosciences 10, 6759-6767.

Nehrke, G., Reichart, G. J., Van Cappellen, P., Meile, C., and Bijma, J., 2007. Dependence of calcite growth rate and $\mathrm{Sr}$ partitioning on solution stoichiometry: Non-Kossel crystal growth. Geochim. Cosmochim. Acta 71, 2240-2249.

Ni, Y., Foster, G. L., Bailey, T., Elliott, T., Schmidt, D. N., Pearson, P. N., Haley, B., and Coath, C., 2007. A core top assessment of proxies for the ocean carbonate system in surface-dwelling foraminifers. Paleoceanography 22, doi:10.1029/2006PA001337.

Ni, Y. Y., 2010. A comparative study of boron isotopes and trace elements of the marine foraminifers during the last glacial maximum and Holocene. Sci. China-Earth Sci. 53, 91-100.

Nürnberg, D., Bijma, J., and Hemleben, C., 1996. Assessing the reliability of magnesium in foraminiferal calcite as a proxy for water mass temperatures. Geochim. Cosmochim. Acta. 
1541 Raitzsch, M., Kuhnert, H., Hathorne, E.C., Groeneveld, J., Bickert, T., 2011. U/Ca in 1542 benthic foraminifers: A proxy for the deep-sea carbonate saturation. Geochem. 1543 Geophys. Geosyst. 12.

Reeder, R. J., 1983. Carbonates: mineralogy and chemistry. Mineralogical Society of America.

Reeder, R. J., 1996. Interaction of divalent cobalt, zinc, cadmium, and barium with the calcite surface during layer growth. Geochim. Cosmochim. Acta 60, 1543-1552.

Reeder, R. J., Nugent, M., Tait, C. D., Morris, D. E., Heald, S. M., Beck, K. M., Hess, W. P., and Lanzirotti, A., 2001. Coprecipitation of Uranium(VI) with Calcite: XAFS, micro-XAS, and luminescence characterization. Geochim. Cosmochim. Acta 65, 3491-3503.

Rickaby, R. E. M. and Elderfield, H., 1999. Planktonic foraminiferal Cd/Ca: Paleonutrients or paleotemperature? Paleoceanography 14, 293-303.

1554

1555

1556

1557

1558

1559

1560

1561

1562

1563

1564

1565

1566

1567

1568

1569

1570

1571

1572

1573

1574

1575

1576

Rink, S., Kühl, M., Bijma, J., and Spero, H. J., 1998. Microsensor studies of photosynthesis and respiration in the symbiotic foraminifer Orbulina universa. Mar. Biol. 131, 583-595.

Ripperger, S., Schiebel, R., Rehkamper, M., and Halliday, A. N., 2008. Cd/Ca ratios of in situ collected planktonic foraminiferal tests. Paleoceanography 23.

Rosenthal, Y., Boyle, E. A., and Labeyrie, L., 1997. Last glacial maximum paleochemistry and deepwater circulation in the Southern Ocean: Evidence from foraminiferal cadmium. Paleoceanography 12, 787-796.

Rosenthal, Y., Boyle, E. A., Labeyrie, L., and Oppo, D., 1995. Glacial enrichments of authigenic Cd and U in Sub-Antarctic Sediments - A climatic control on the elements' oceanic budget. Paleoceanography 10, 395-413.

Russell, A. D., Emerson, S., Nelson, B. K., Erez, J., and Lea, D. W., 1994. Uranium in foraminiferal calcite as a recorder of seawater uranium concentrations. Geochim. Cosmochim. Acta 58, 671-681.

Russell, A. D., Hönisch, B., Spero, H. J., and Lea, D. W., 2004. Effects of changes in seawater carbonate ion concentration and temperature on shell $\mathrm{U} / \mathrm{Ca}, \mathrm{Mg} / \mathrm{Ca}$, and $\mathrm{Sr} / \mathrm{Ca}$ of planktonic foraminifera. Geochim. Cosmochim. Acta 68, 4347-4361.

Sakae, N., Yokoyama, T., Yoshimura, K., and Tarutani, T., 1979. Chemical composition of calcareous deposits in caves. J. Speleol. Soc. Jpn. 4, 57-62.

Sanyal, A., Bijma, J., Spero, H. J., \& Lea, D. W. (2001). Empirical relationship between $\mathrm{pH}$ and the boron isotopic composition of Globigerinoides sacculifer: Implications for the boron isotope paleo-pH proxy. Paleoceanography, 16 (5), 515-519. 
Spero, H. J. and Parker, S. L., 1985. Photosynthesis in the symbiotic planktonic foraminifer Orbulina universa, and its potential contribution to oceanic primary productivity. Journal of Foraminiferal Research 15, 273-281.

Spero, H. J., 1988. Ultrastructural examination of chamber morphogenesis and biomineralization in the planktonic foraminifer Orbulina universa. Marine Biology 99, 9-20.

Spero, H. J., Eggins, S. M., Russell, A. D., Vetter, L., Kilburn, M. R., and Honisch, B., 2015. Timing and mechanism for intratest $\mathrm{Mg} / \mathrm{Ca}$ variability in a living planktic foraminifer. Earth Planet. Sci. Lett. 409, 32-42.

Stoll, H. M., Schrag, D. P., and Clemens, S. C., 1999. Are seawater Sr/Ca variations preserved in Quaternary foraminifera? Geochim. Cosmochim. Acta 63, 35353547.

Stumm, W., Morgan, J.J., 1996. Aquatic Chemistry, 2nd ed. John Wiley.

Sunda, W.G., 1989. Trace Metal Interactions with Marine Phytoplankton. Biological Oceanography 6, 411-422.

Tesoriero, A. J. and Pankow, J. F., 1996. Solid solution partitioning of $\mathrm{Sr}^{2+}, \mathrm{Ba}^{2+}$, and $\mathrm{Cd}^{2+}$ to calcite. Geochim. Cosmochim. Acta 60, 1053-1063.

Uchikawa, J., Penman, D. E., Zachos, J. C., \& Zeebe, R. E. (2015). Experimental evidence for kinetic effects on $\mathrm{B} / \mathrm{Ca}$ in synthetic calcite: Implications for potential $\mathrm{B}(\mathrm{OH})_{4}{ }^{-}$and $\mathrm{B}(\mathrm{OH})_{3}$ incorporation. Geochimica et Cosmochimica Acta, 150(C), 171-191.

Uppström, L. R., 1974. Boron/Chlorinity Ratio of Deep-Sea Water from the Pacific Ocean. Deep-Sea Research 21, 161-162.

van Heuven, S., D. Pierrot, J.W.B. Rae, E. Lewis, and D.W.R. Wallace, 2011. MATLAB Program Developed for $\mathrm{CO}_{2}$ System Calculations. In: ORNL/CDIAC-105b. Carbon Dioxide Information Analysis Center, O. R. N. and Laboratory, U. S. D. o. E. Eds.), Oak Ridge, Tennessee.

Wartel, M., Skiker, M., Auger, Y., Boughriet, A., Puskaric, E., and Guegueniat, P., 1991. Seasonal variation of $\mathrm{Mn}-2+$ adsorption on to calcareious surfaces in the English Channel, and its implication on the manganese distribution coefficient. Mar. Chem. 36, 85-105.

Watson, E. B., 1996. Surface enrichment and trace-element uptake during crystal growth. Geochim. Cosmochim. Acta 60, 5013-5020.

Watson, E. B., 2004. A conceptual model for near-surface kinetic controls on the traceelement and stable isotope composition of abiogenic calcite crystals. Geochim. Cosmochim. Acta 68, 1473-1488. 
1618 White, A., 1978. Sodium coprecipitation in calcite and dolomite. Chem. Geol. 23, 65-72.

1619 Wit, J. C., de Nooijer, L. J., Wolthers, M., and Reichart, G. J., 2013. A novel salinity proxy based on $\mathrm{Na}$ incorporation into foraminiferal calcite. Biogeosciences 10, 6375-6387.

1622 Wolthers, M., Nehrke, G., Gustafsson, J. P., and Van Cappellen, P., 2012. Calcite growth kinetics: Modeling the effect of solution stoichiometry. Geochim. Cosmochim. Acta 77, 121-134.

1625 Yu, J., Day, J., Greaves, M., and Elderfield, H., 2005. Determination of multi1626 element/calcium ratios in foraminiferal calcite by quadropole ICP-MS and its application for paleoceanographic studies. Geochem. Geophys. Geosyst. 6, doi: 10.1029/2005GC000964.

1629 Yu, J., Elderfield, H., \& Hönisch, B. (2007). B/Ca in planktonic foraminifera as a proxy for surface seawater $\mathrm{pH}$. Paleoceanography, 22(2).

1631 Yu, J. M., Elderfield, H., Jin, Z. D., and Booth, L., 2008. A strong temperature effect on 1632 $\mathrm{U} / \mathrm{Ca}$ in planktonic foraminiferal carbonates. Geochim. Cosmochim. Acta 72, 4988-5000.

1634 Yu, J., Thornalley, D. J. R., Rae, J., McCave, I. N. (2013) Calibration and application of $\mathrm{B} / \mathrm{Ca}, \mathrm{Cd} / \mathrm{Ca}$, and $\delta^{11} \mathrm{~B}$ in Neogloboquadrina pachyderma (sinistral) to constrain $\mathrm{CO}_{2}$ uptake in the subpolar North Atlantic during the last deglaciation. Paleoceanography, 28(2), 237-252.

Zeebe, R. E. and Sanyal, A., 2002. Comparison of two potential strategies of planktonic foraminifera for house building: $\mathrm{Mg} 2+$ or $\mathrm{H}+$ removal? Geochim. Cosmochim. Acta 66, 1159-1169.

1642 Zeebe, R. E. and Wolf-Gladrow, D. A., 2001. $\mathrm{CO}_{2}$ in seawater: Equilibrium, kinetics, 1643 isotopes. Elsevier. 


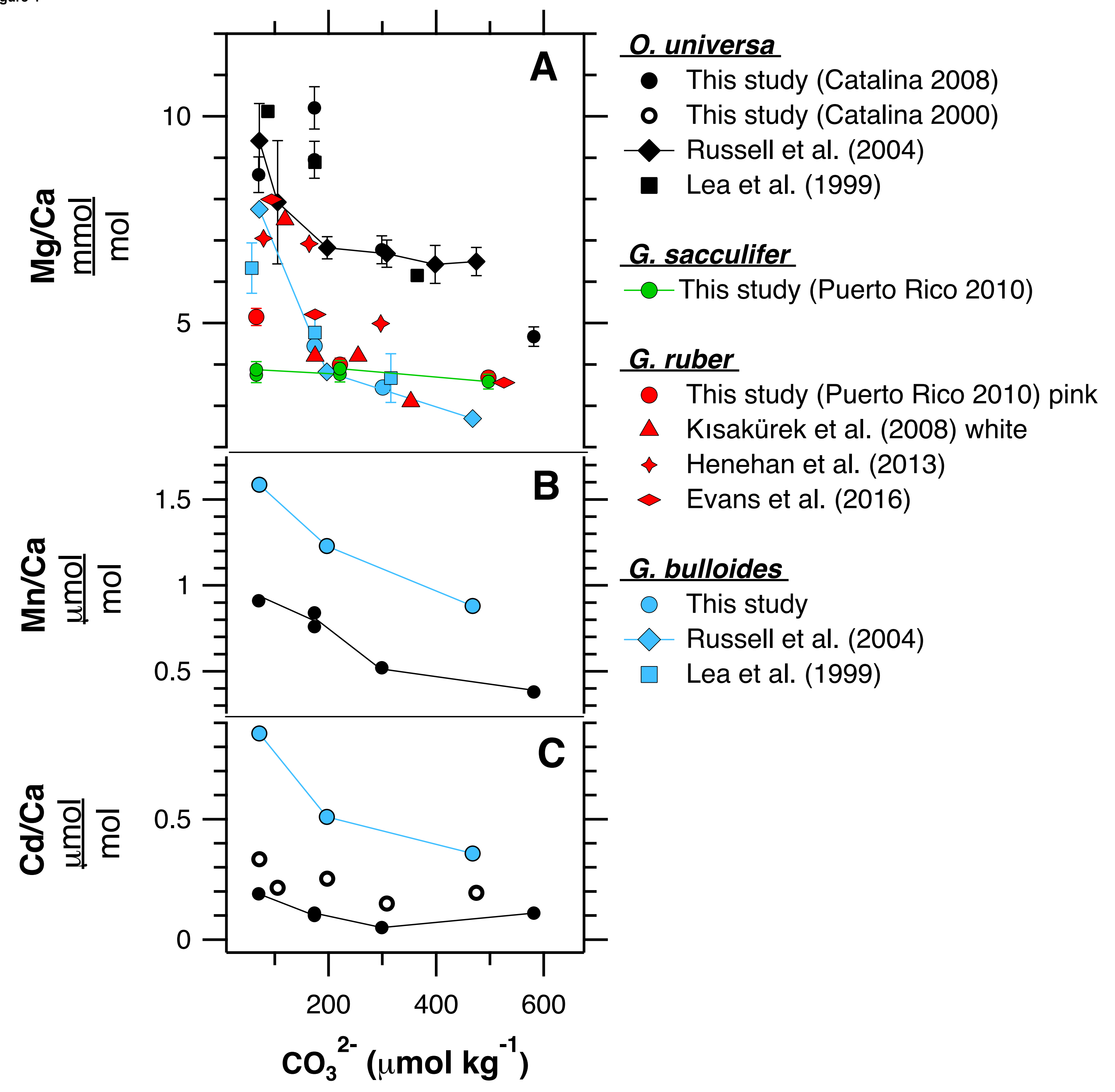



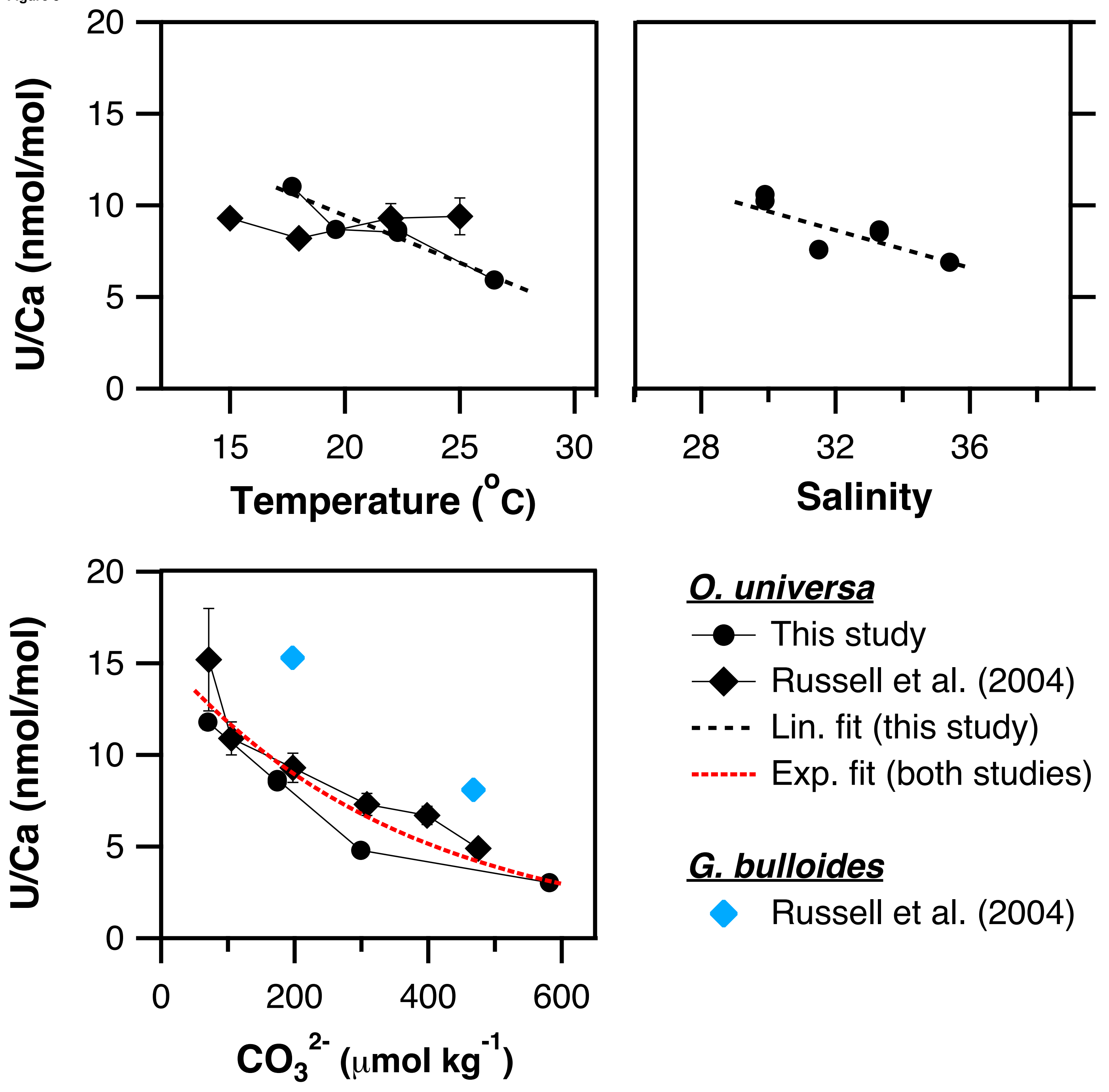

O. universa

- This study

$\checkmark$ Russell et al. (2004)

.... Lin. fit (this study)

------ Exp. fit (both studies)

G. bulloides

- Russell et al. (2004) 

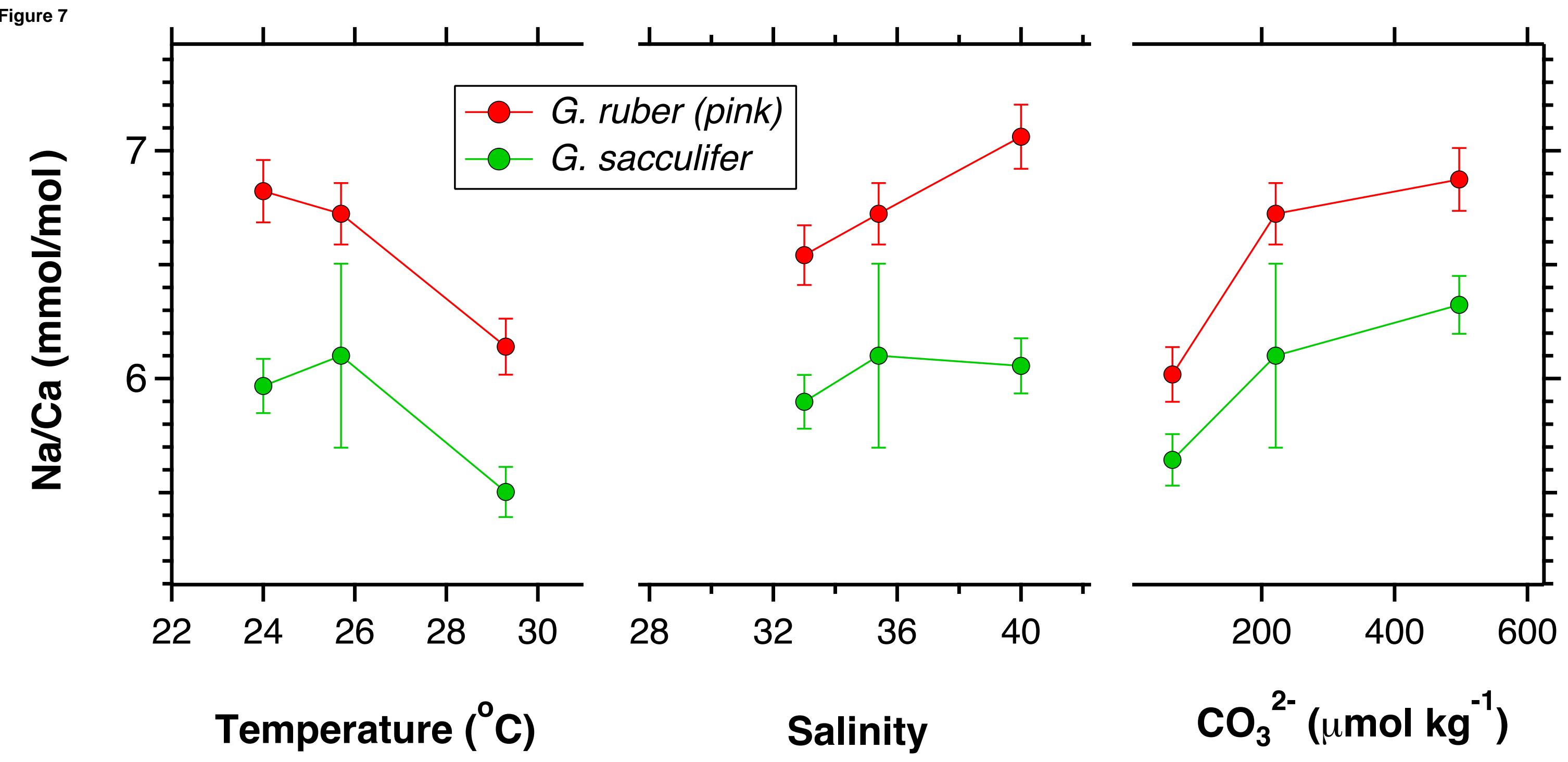


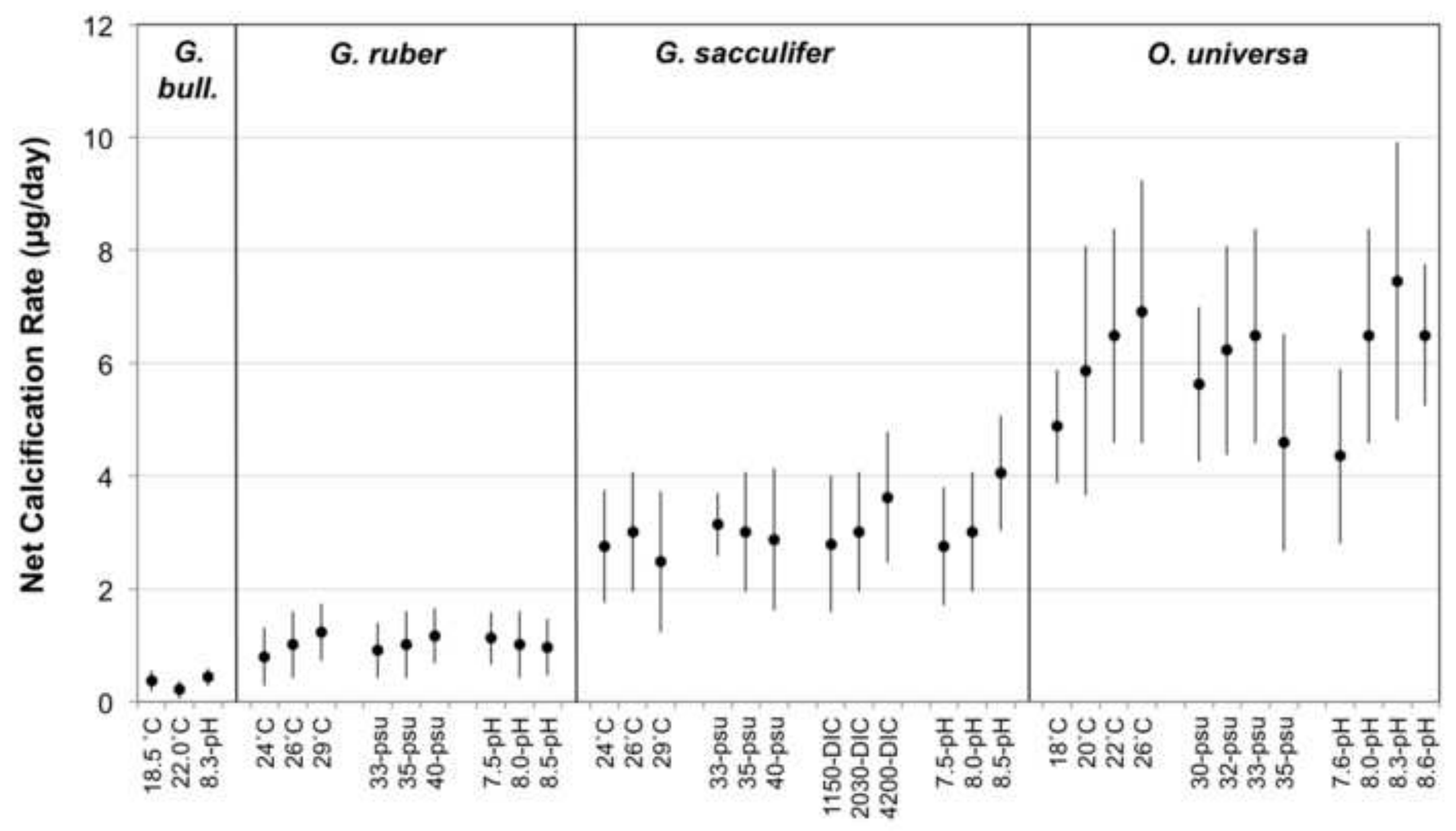



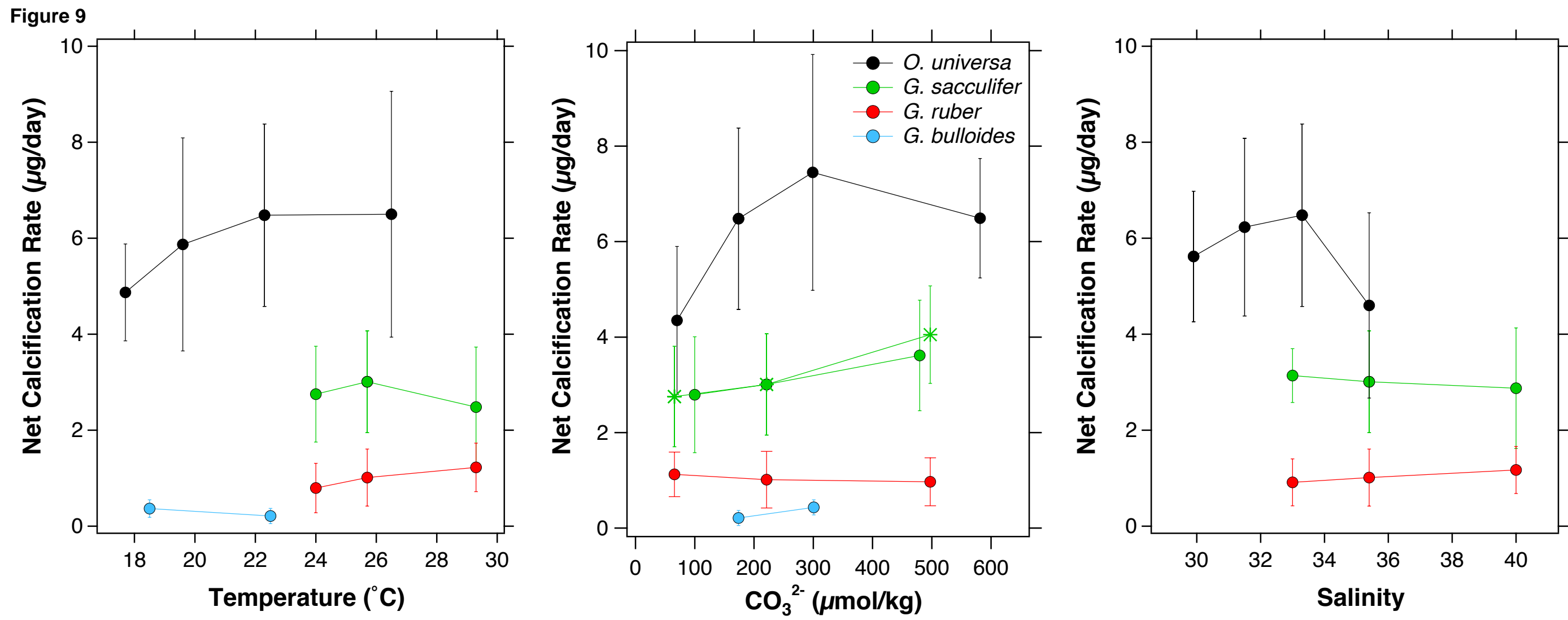
Inorganic calcite

$-\mathbf{D} \mathrm{D}_{\mathrm{Sr}}, \Omega=5$

$\rightarrow \mathrm{D}_{\mathrm{Sr}}, \Omega=12$

Foraminiferal calcite

Measured values:

- $\mathrm{D}_{\mathrm{Sr}}, \mathrm{G}$. sacc, changing DIC

- $\mathrm{D}_{\mathrm{Sr}}, \mathrm{G}$. sacc, changing $\mathrm{pH}$

$\downarrow D_{S r}, O$. universa, Paleocene sw

$-\rightarrow$. Calculated internal solution

$\diamond \quad$ Calculated internal solution

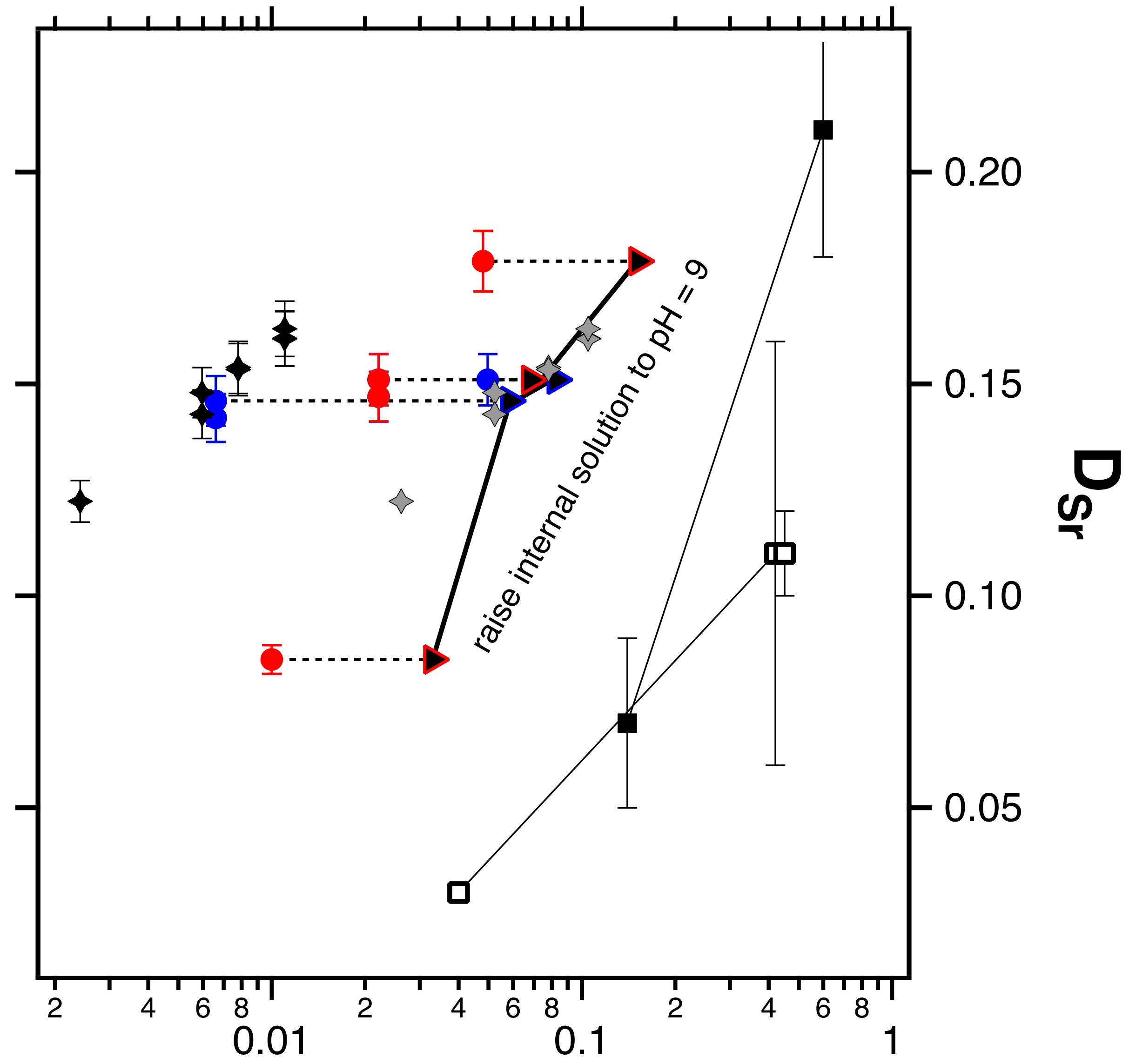

$\left[\mathrm{CO}_{3}{ }^{2-}\right] /\left[\mathrm{Ca}^{2+}\right]$ of growth solution $(\mathrm{mol} / \mathrm{mol})$ 
Figure 11

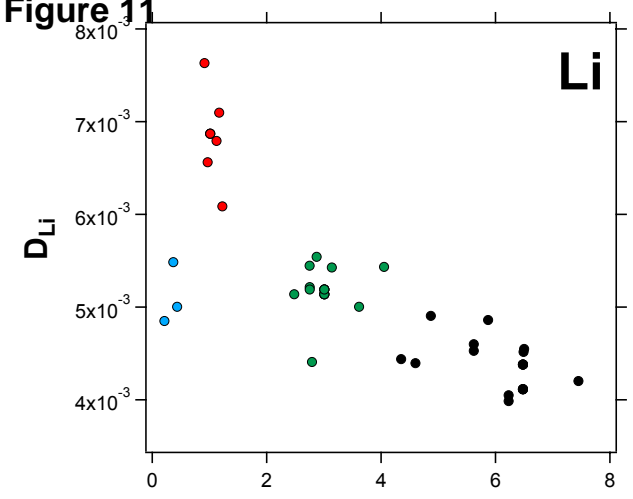

Net Calcification Rate ( $\mu \mathrm{g} / \mathrm{day})$
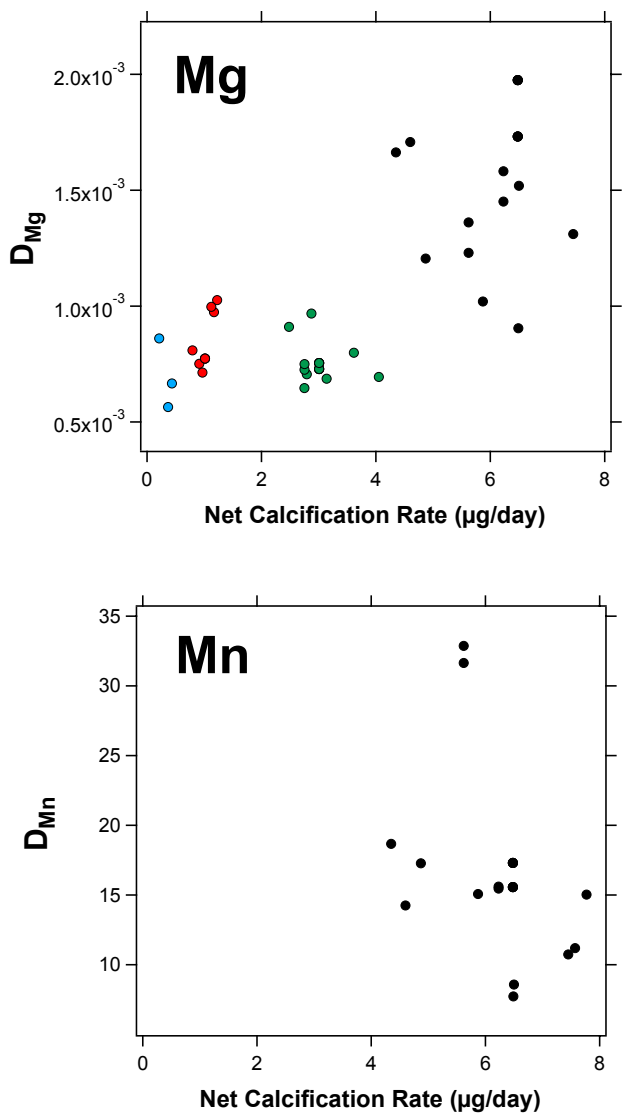
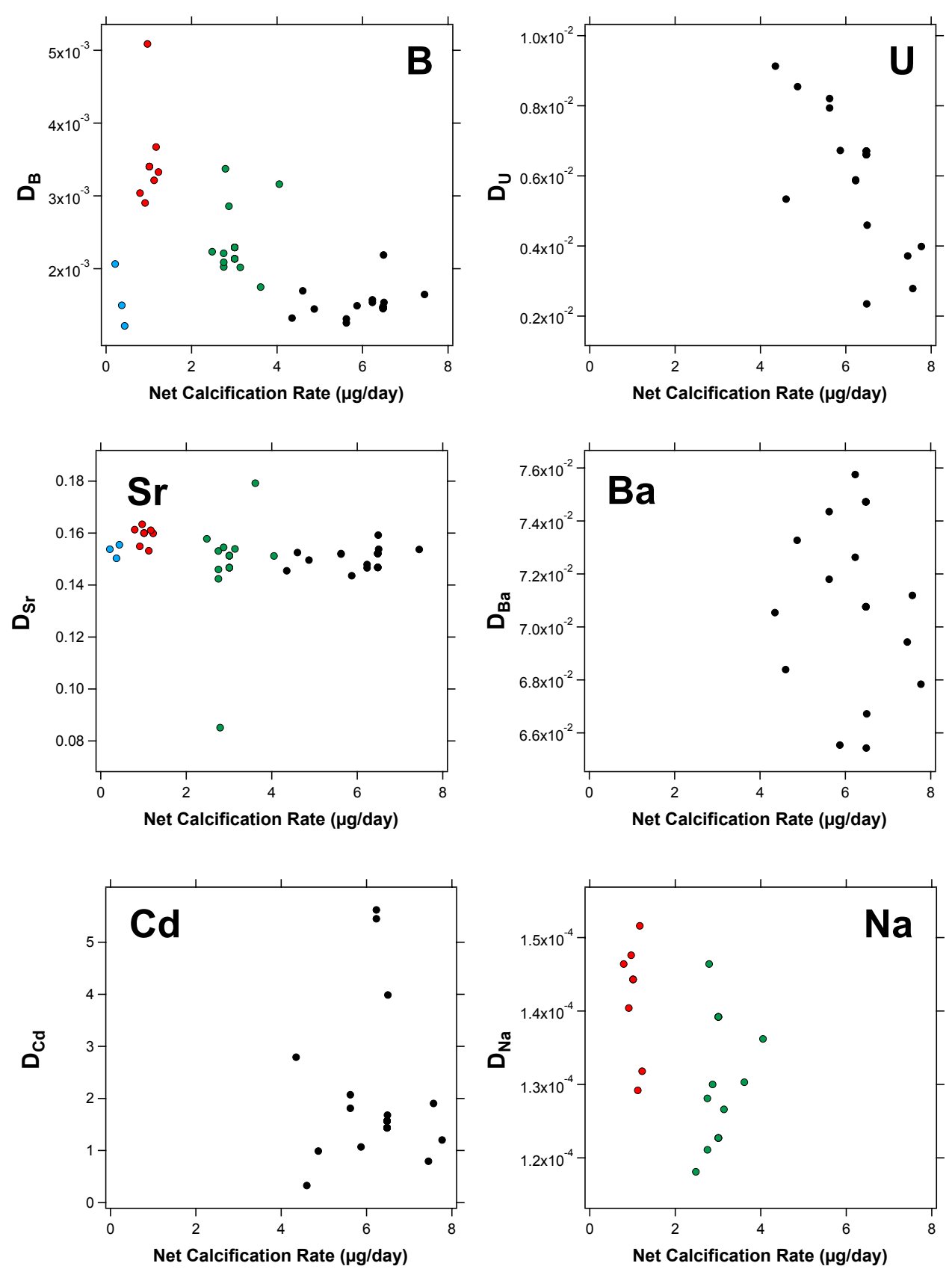
Figure 12

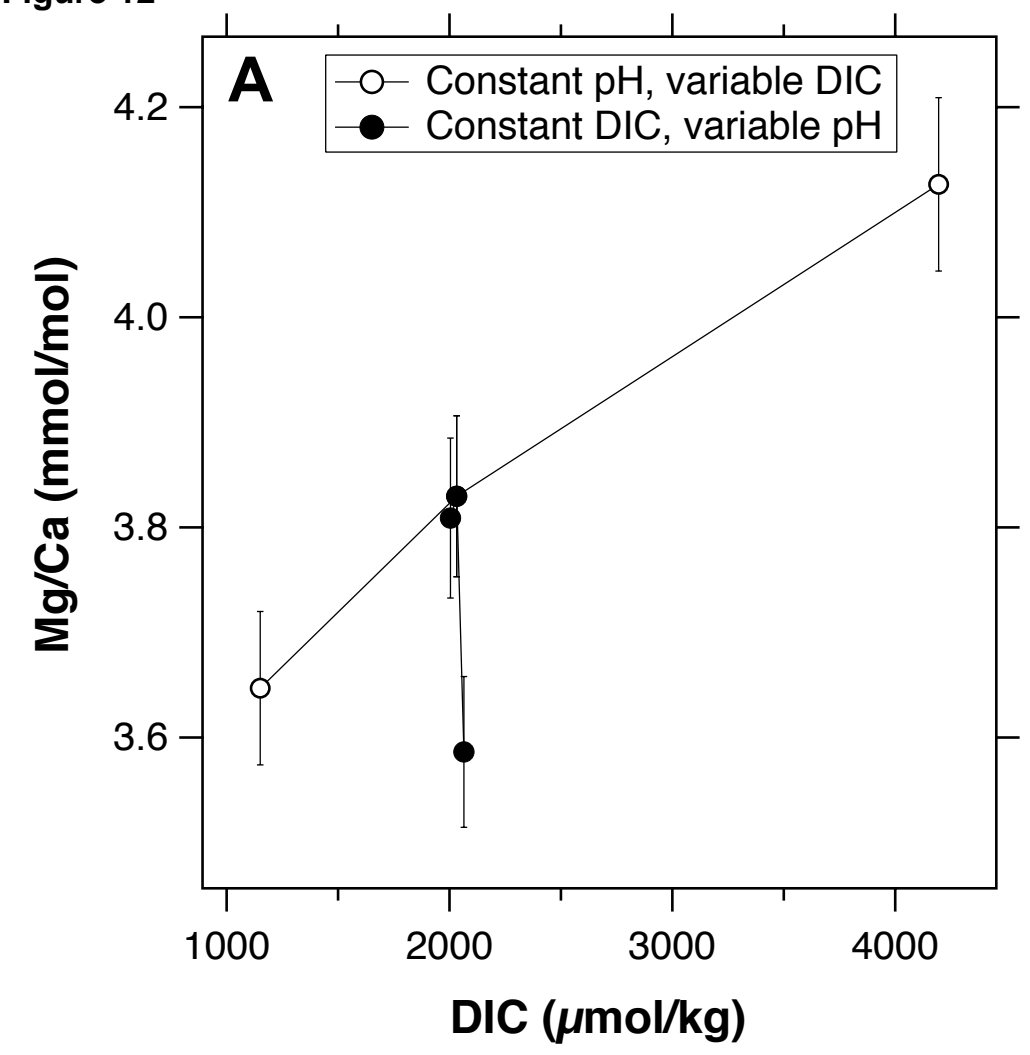

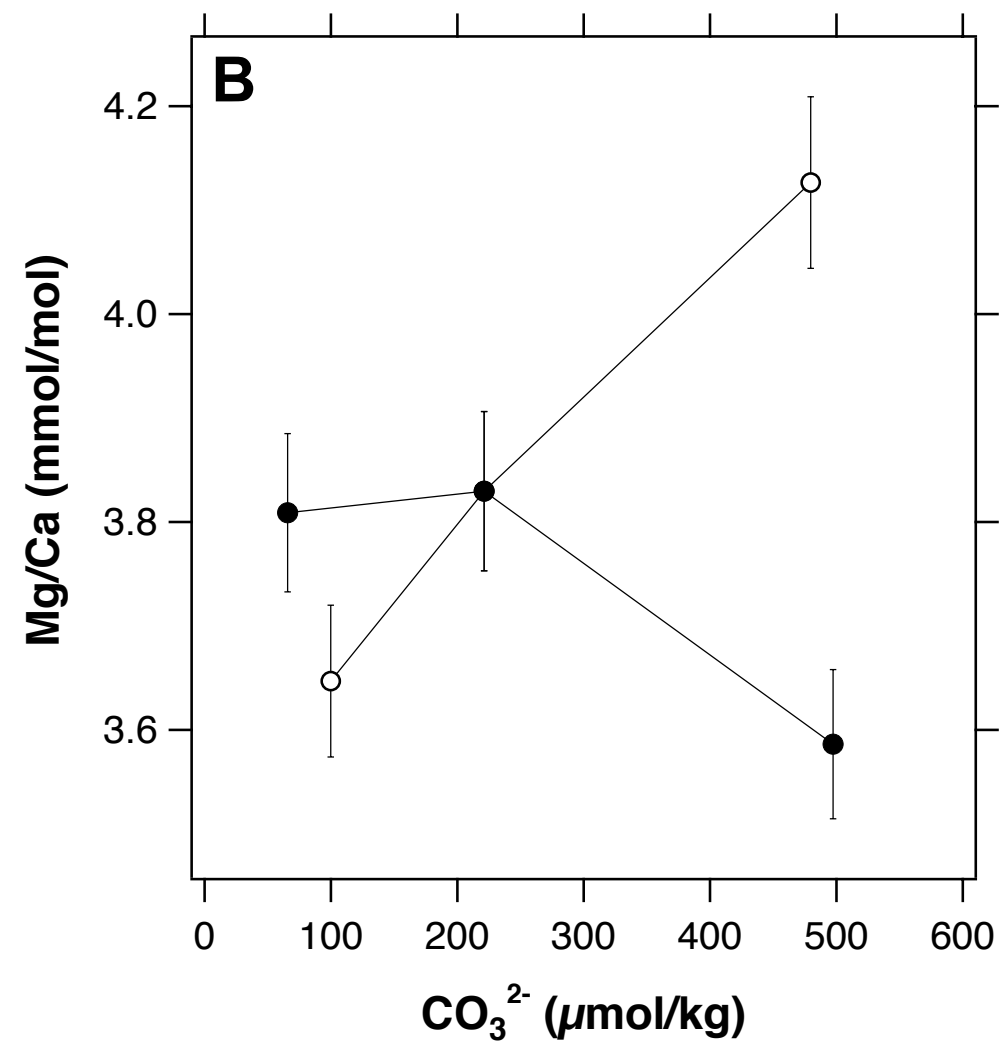




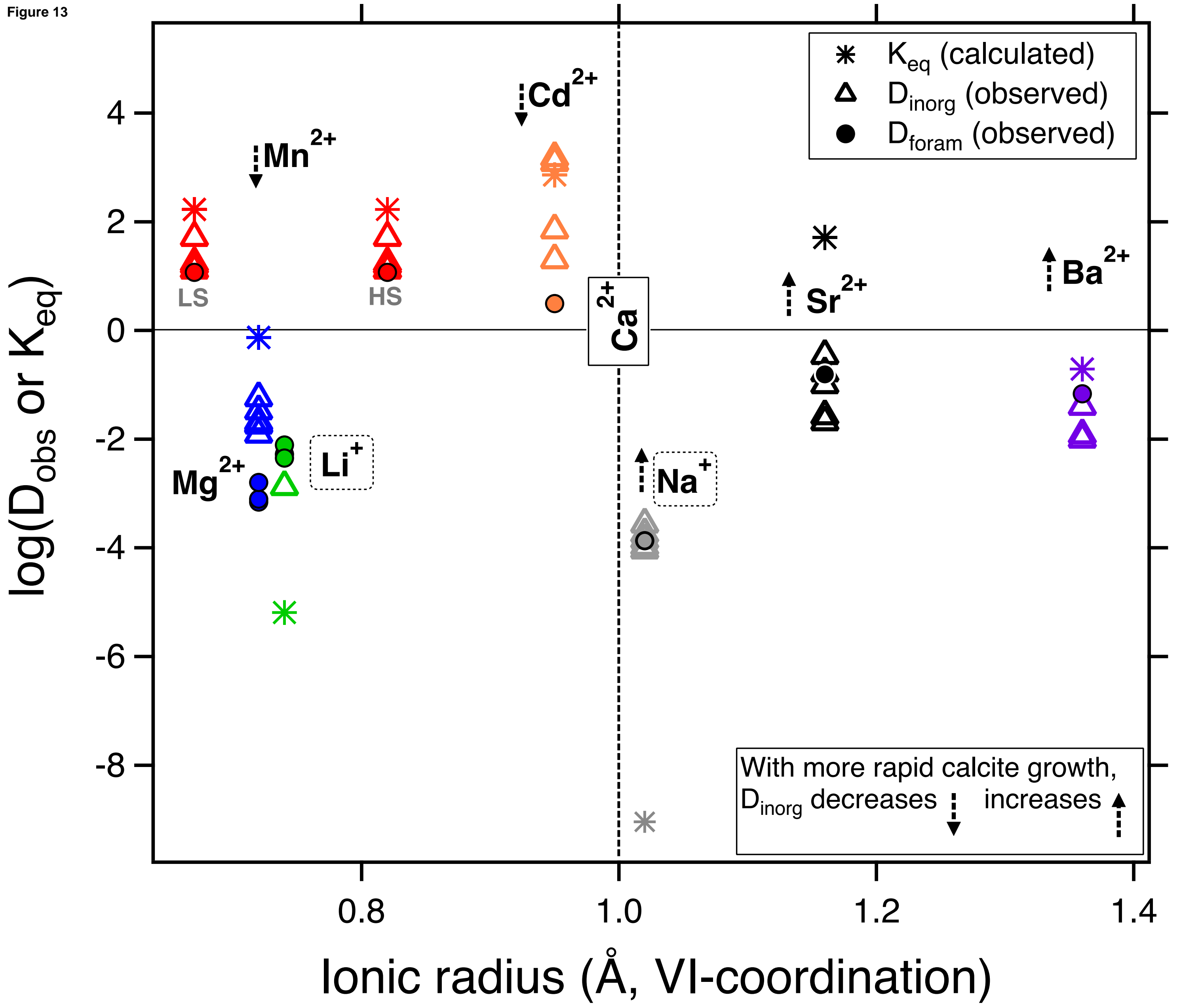


Figure 14

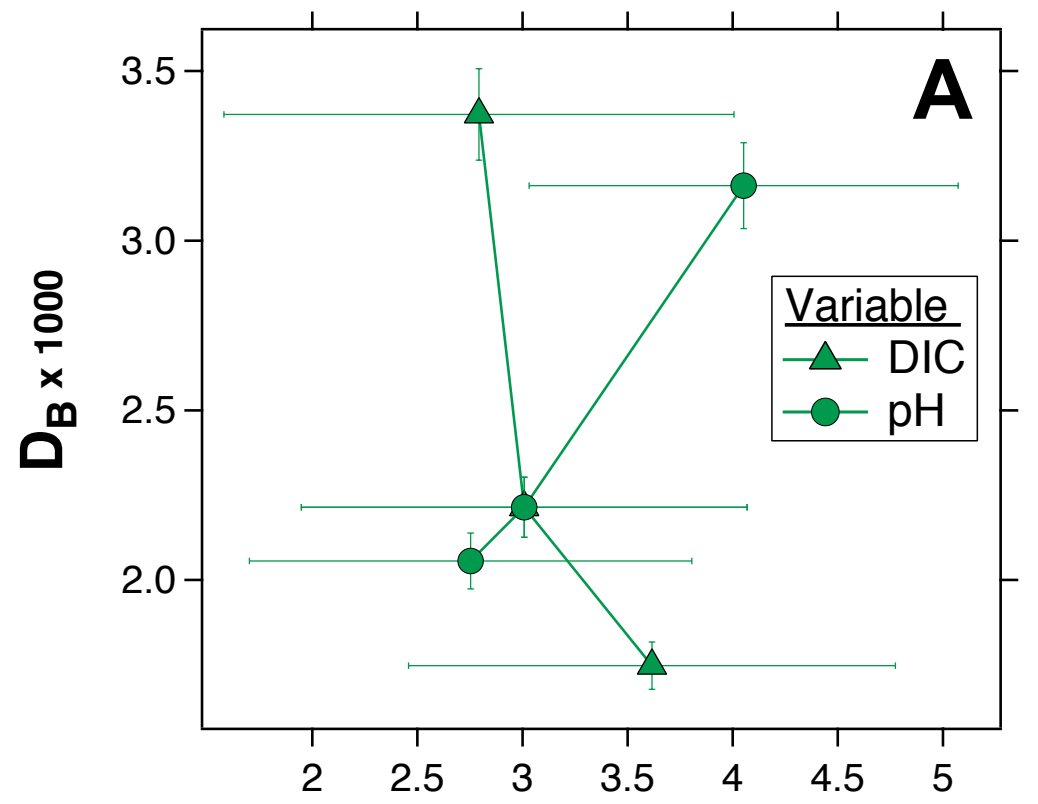

Net calcification rate ( $\mu \mathrm{g} / \mathrm{day})$
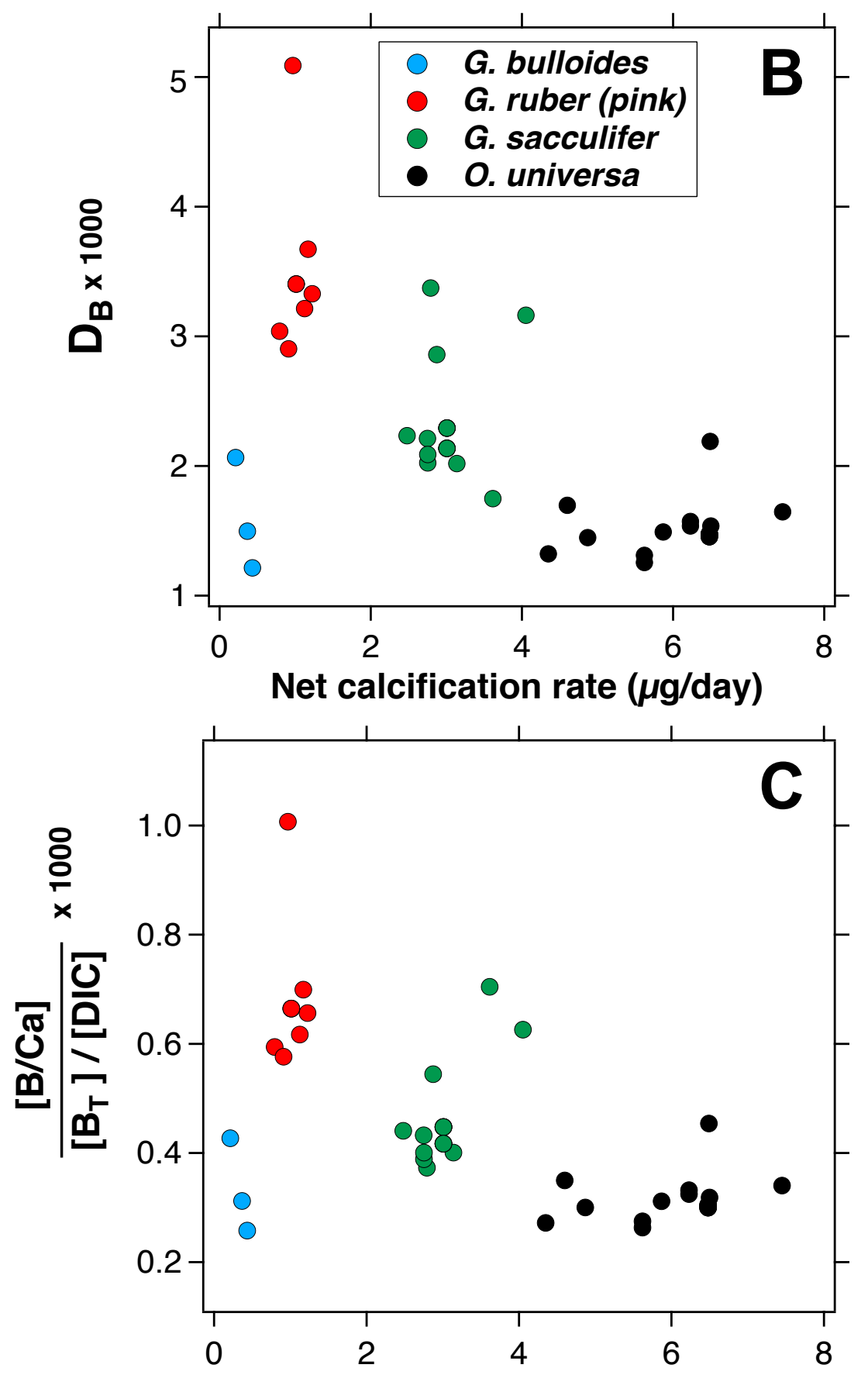

Net calcification rate $(\mu \mathrm{g} / \mathrm{day})$ 